\title{
Asymmetric Synthesis of Tailor-Made Amino Acids Using Chiral Ni(II) Complexes of Schiff Bases. An Update of the Recent Literature
}

\author{
Yupiao Zou ${ }^{1}$, Jianlin Han ${ }^{1, *(D)}$, Ashot S. Saghyan ${ }^{2,3}$, Anna F. Mkrtchyan ${ }^{2,3}{ }^{\mathbb{D}}$, \\ Hiroyuki Konno ${ }^{4}\left(\mathbb{D}\right.$, Hiroki Moriwaki ${ }^{5}$, Kunisuke Izawa ${ }^{5}$ and Vadim A. Soloshonok $6,7, *$ (D) \\ 1 Jiangsu Co-Innovation Center of Efficient Processing and Utilization of Forest Resources, College of \\ Chemical Engineering, Nanjing Forestry University, Nanjing 210037, China; zouyupiaog1@163.com \\ 2 Institute of Pharmacy, Yerevan State University, 1 Alex Manoogian Str., Yerevan 0025, Armenia; \\ saghyan@ysu.am (A.S.S.); anna_mkrtchyan@ysu.am (A.F.M.) \\ 3 Scientific and Production Center "Armbiotechnology" of NAS RA, 14 Gyurjyan Str., Yerevan 0056, Armenia \\ 4 Department of Biological Engineering, Graduate School of Science and Engineering, Yamagata University, \\ Yonezawa, Yamagata 992-8510, Japan; konno@yz.yamagata-u.ac.jp \\ 5 Hamari Chemical Ltd., 1-4-29 Kunijima, Higashi-Yodogawa-ku, Osaka 533-0024, Japan; \\ hiroki-moriwaki@hamari.co.jp (H.M.); kunisuke-izawa@hamari.co.jp (K.I.) \\ 6 Department of Organic Chemistry I, Faculty of Chemistry, University of the Basque Country UPV/EHU, \\ Paseo Manuel Lardizábal 3, 20018 San Sebastián, Spain \\ 7 IKERBASQUE, Basque Foundation for Science, Alameda Urquijo 36-5, Plaza Bizkaia, 48011 Bilbao, Spain \\ * $\quad$ Correspondence: hanjl@njfu.edu.cn (J.H.); vadym.soloshonok@ehu.es (V.A.S.); Tel.: +34-943-015-177 (V.A.S.) \\ Academic Editor: Roman Dembinski \\ Received: 25 May 2020; Accepted: 11 June 2020; Published: 12 June 2020

\begin{abstract}
Tailor-made amino acids are indispensable structural components of modern medicinal chemistry and drug design. Consequently, stereo-controlled preparation of amino acids is the area of high research activity. Over last decade, application of Ni(II) complexes of Schiff bases derived from glycine and chiral tridentate ligands has emerged as a leading methodology for the synthesis of various structural types of amino acids. This review article summarizes examples of asymmetric synthesis of tailor-made $\alpha$-amino acids via the corresponding $\mathrm{Ni}$ (II) complexes, reported in the literature over the last four years. A general overview of this methodology is provided, with the emphasis given to practicality, scalability, cost-structure and recyclability of the chiral tridentate ligands.
\end{abstract}

Keywords: tailor-made amino acids; Schiff bases; asymmetric synthesis; chiral tridentate ligands; square-planar $\mathrm{Ni}(\mathrm{II})$ complexes

\section{Introduction}

Tailor-made amino acids (AAs) [1] are essential structural features of modern medicinal chemistry and drug design. The presence of orthogonal amino and carboxyl groups in adaptable proximity $(\alpha-$, $\beta-, \gamma-$, etc.), combined with elements of chirality and diverse side chains, provides an exceptional three-dimensional structural framework with a high degree of chemical/biological functionality. These properties make AAs ideally suited for syntheses of complex molecules, highly diverse elements for SAR campaigns, basic components of modern pharmaceuticals [2-5]. In fact, over $30 \%$ of small-molecule drugs contain residues of tailor-made AAs [2,6-8], while peptidomimetics and peptide class drugs are fully based on AAs [9-12]. Consequently, the interest in development of synthetic approached for the preparation of tailor-made AA is at an all-time high [13-22]. Over the last decade, transformations of chiral Ni(II) complexes of Schiff bases derived from tridentate ligands and 
AAs (Scheme 1), have emerged as a leading methodology for asymmetric synthesis of tailor-made AAs $[23,24]$.



Scheme 1. Asymmetric synthesis of tailor-made amino acid via Ni(II) complexes of Schiff bases.

As presented in Scheme 1, the original Belokon' [25-27] tridentate ligand (S)-1, or its more recent modifications $[23,24,28,29]$ can be efficiently used for direct reactions with unprotected AAs to obtain Ni complexes 3 . This process allows for efficient deracemization, dynamic thermodynamic resolution, or $(S)$ to $(R)$ interconversion of unprotected $\alpha$ - [30-33] and $\beta$-AAs [34]. A more general approach includes preparation of the glycine Schiff base $\mathrm{Ni}(\mathrm{II})$ complex 2, followed by transformation of the glycine moiety. Most frequently used reaction types include, but not limited to, alkyl halide alkylations [35,36] 4, $\alpha, \alpha$-dialkylations [37,38] 5, secondary alkyl halide alkylations [39] 6, $\alpha, \omega$-dialkylations [40,41] 7, aldol [42,43] 8, Mannich [44,45] 9 and Michael [46,47] 10 addition reactions. Synthesis of various $\beta$-AAs of types 11 [48] and 15 [49], as well as multiple step processes allowing access to several types of cyclic derivatives 12-14, can be conveniently performed [50-52].

Application of $\mathrm{Ni}(\mathrm{II})$ complexes methodology for general asymmetric synthesis of tailor-made AAs [53-55], as well as special types of AAs such as fluorine-containing [56] and isotope-labelled [57], was previously reported in the corresponding reviews. The most recent update of this methodology [58], covering the literature from 2013 through the end of 2016, was published in 2017. In this review article, 
we summarize examples of asymmetric synthesis of tailor-made $\alpha$-AAs via the corresponding $\mathrm{Ni}(\mathrm{II})$ complexes, reported in the literature over the last four years. Special emphasis is given to the aspects of practicality, scalability, cost-structure and recyclability of chiral tridentate ligands.

\section{Large-Scale Synthesis of Chiral Ligands and Gly Schiff Base Complexes}

The use of Ni(II) complexes of Gly or Ala-derived Schiff bases has been demonstrated to be one of the most efficient and practical methods for the synthesis of tailor-made AAs under simple and mild conditions. Thus, considerable efforts on the development of chiral tridentate ligands based on $(R)$ - or (S)-N-(2-benzoylphenyl)-1-benzylpyrrolidine-2-carboxamide (1) [25-27] have been made to improve their stereo-controlling properties (Figure 1) [54-57].<smiles>O=C(c1ccccc1)c1ccccc1NC(=O)[C@@H]1CCCN1Cc1ccccc1</smiles>

(S)-1<smiles>O=C(c1ccccc1)c1cc(Cl)ccc1NC(=O)[C@@H]1CCCN1Cc1ccc(Cl)c(Cl)c1</smiles>

$(S)-16$

Figure 1. Chiral tridentate ligands.

Recently, an important achievement in this area was the discovery of the Soloshonok ligand 16 (Figure 1). This new proline-derived ligand 16, $(R)$ - and (S)-N-(2-benzoyl-4-chlorophenyl)-1-(3,4-dichlorobenzyl)pyrrolidine-2-carboxamide demonstrates excellent stereo-controlling ability and easily recyclable property, which has been successfully used in the chemical dynamic kinetic resolutions of $\alpha$ - and $\beta$-amino acids [32,34].

In 2017, a scale-up synthetic method for the preparation of this trichlorinated ligand $\mathbf{1 6}$ was reported (Scheme 2), which used commercially available D-proline as the starting material [59].<smiles>O=C(O)C1CCCN1</smiles>

1) $\mathrm{KOH}, i-\mathrm{PrOH}, 40^{\circ} \mathrm{C}, 4 \mathrm{~h}$.

2) $\mathrm{HCl}, \mathrm{pH}=4-6$<smiles>O=C(O)C1CCCN1Cc1ccc(Cl)c(Cl)c1</smiles>

17<smiles>Nc1ccc(Cl)cc1C(=O)c1ccccc1</smiles>

1) $\mathrm{PCl}_{5}, \mathrm{PhCl}, 8^{\circ} \mathrm{C}, 30 \mathrm{~min}$

2) $20^{\circ} \mathrm{C}, 1.5 \mathrm{~h}$

3) $\mathrm{MeOH}$<smiles>O=C(c1ccccc1)c1cc(Cl)ccc1NC(=O)[C@@H]1CCCN1Cc1ccc(Cl)c(Cl)c1</smiles>



$\mathrm{MeOH}, 65^{\circ} \mathrm{C}, 4-6 \mathrm{~h}$



Scheme 2. Large-scale synthesis of ligand 16 and complex 18. 
The reaction between D-proline and 3,4-dichlorobenzyl chloride was carried out in presence of inorganic base $\mathrm{KOH}$ with $i$-PrOH as a solvent at $40^{\circ} \mathrm{C}$ for $4 \mathrm{~h}$, followed by the treatment of hydrochloric acid to $\mathrm{pH}$ of 4-6, resulting in (3,4-dichlorobenzyl)-D-proline (17) as an off-white powder in $88 \%$ yield. The reaction of compound 17 with 2-amino-5-chlorobenzophenone with the use of $\mathrm{PCl}_{5}$ in chlorobenzene afforded the ligand $\mathbf{1 6}$ in $81 \%$ yield (total crude yield). The crude product $\mathbf{1 6}$ could be recrystallized from $\mathrm{MeOH}$ to the fine white needles. In particular, this method was reliably reproduced on a $\mathrm{kg}$ scale. In the initial study on the synthesis of the Ni complex 18 from the ligand 16, an inorganic base, $\mathrm{Na}_{2} \mathrm{CO}_{3}$ was used. The main disadvantage of this methodology is that the reaction mixture is quite viscous for stirring at the initial stage. Furthermore, significant gas releases from the system during the workup step.

In 2020, Romoff, Soloshonok, and co-workers developed an improved synthetic method for the synthesis of Ni complex 18 with the use of the soluble organic base 1,8-diazabicyclo[5.4.0]undec-7-ene $(\mathrm{DBU})$ in the assembly step. Stirring $(S)$ - and $(R)-\mathbf{1 6}$, glycine, $\mathrm{Ni}(\mathrm{OAc})_{2} \cdot 4 \mathrm{H}_{2} \mathrm{O}$ and $\mathrm{DBU}$ in $\mathrm{MeOH}$ in a $50 \mathrm{~L}$ jacketed glass reactor at $68-70{ }^{\circ} \mathrm{C}$ for $21 \mathrm{~h}$ afforded the desired $\mathrm{Ni}$ complex 18 as an orange solid in $98.9 \%$ yield with $>99 \%$ chemical purity. In this report, the chiral integrity of Ni complex 18 was also carefully examined, and the results indicate that no detectable undesirable enantiomer in the product was found under the improved reaction conditions ( $>99.5 \%$ chiral purity by chiral HPLC) (Scheme 3) [23]. It should be mentioned that this method could be conducted on a multi-kilogram scale with high efficiency, which demonstrates high utility of this method for the synthesis of tailor-made AAs.

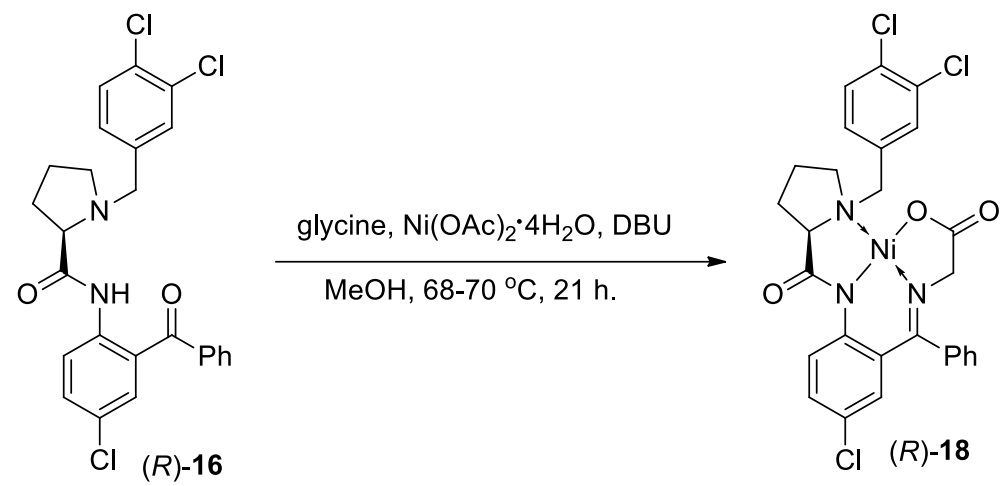

Scheme 3. Synthesis of Ni(II) complex 18 from 16.

Another chiral tridentate ligand, (3Z,5Z)-2,7-dihydro- $1 H$-azepine-derived Hamari ligand 19, also has been developed for the synthesis of AAs. Comparing with the Soloshonok ligand 16, Hamari ligand contains a chiral binaphthalene based azepine moiety (Figure 2).



Figure 2. Structure of Hamari ligand.

In particular, Hamari ligand 19 is chemically stable axial chirality, and no racemization was found during the related reactions. Actually, Hamari ligand has been successfully applied in several 
asymmetric reactions with excellent stereoselectivities, including dynamic kinetic resolution of $\alpha$-amino acids and alkylation reaction of its related $\mathrm{Ni}(\mathrm{II})$ complex [31,60].

In 2014, Hamari developed a four-step synthetic method for the synthesis of ligand 19 from the commercially available chiral binaphthol (Scheme 4a) [60], which was through the sequence of bromination, alkylation with allylamine, removal of allyl protecting group and alkylation with a total $57 \%$ yield for the last three steps. This method suffered from the use of silica gel column purifications, which limited its application in large-scale manufacturing.


Scheme 4. Methods for the synthesis of Hamari ligand 19 ((a) synthetic method from chiral binaphthol;

(b) synthetic method via a one-step substitution alkylation reaction).

In 2019, an improved method for the preparation of Hamari ligand 19 was developed via a one-step substitution alkylation reaction of bis-bromide 20 by 2-amino- $N$-(2-benzoyl-4-chlorophenyl)acetamide hydrochloric salt (24) [61]. After careful optimization of reaction conditions, excellent yield (90\%) was obtained when the reaction was conducted with the use of 6 equiv of $\mathrm{Na}_{2} \mathrm{CO}_{3}, 4$ volumes of $\mathrm{AcO} i \mathrm{Pr}$ and 6 volumes of water at $78^{\circ} \mathrm{C}$ for $22 \mathrm{~h}$. Furthermore, this reaction could be performed in a large-scale (500 g) preparation (Scheme $4 \mathrm{~b}$ ).

A two-step method for the synthesis of glycinamide hydrochloride 24 was presented in Scheme 5, which used Boc-glycine as the starting material. The reaction of Boc-glycine with 2-amino-5-chlorobenzephenone in presence of pivaloyl chloride with 2,6-lutidine as a base at $50{ }^{\circ} \mathrm{C}$ for $6 \mathrm{~h}$ afforded the glycinamide $\mathbf{2 5}$ with $92 \%$ chemical yield. Boc-protecting group in glycinamide $\mathbf{2 5}$ was removed in the presence of $\mathrm{HCl}$ for $5 \mathrm{~h}$ at $60{ }^{\circ} \mathrm{C}$ to give the compound 24 in $95 \%$ yield. 


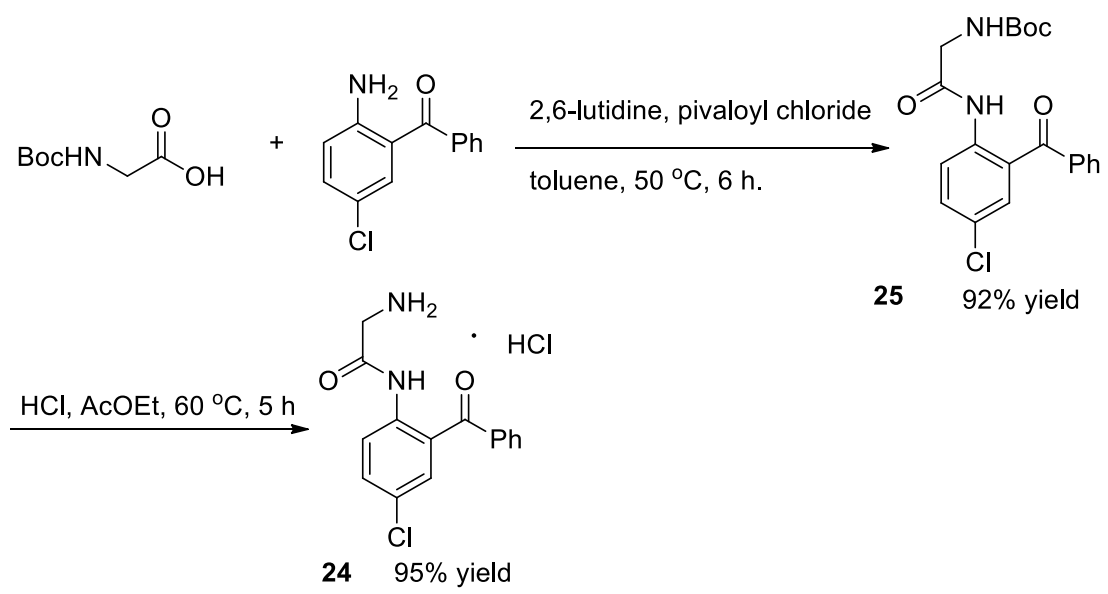

Scheme 5. Preparation of glycinamide hydrochloride 24 .

\section{Asymmetric Synthesis of $\alpha$-Deuterated- $\alpha$-Amino Acids}

$\alpha$-Deuterated AAs belong to a special type of isotopically labeled compounds, and also play important roles in the biochemical researches. Thus, development of mild and efficient strategy for the preparation of these compounds becomes necessary and urgent. In 2017, Takeda and co-authors successfully used the three tridentate ligands 1,16 and 19 in the synthesis of $\alpha$-D- $\alpha$-amino acids via dynamic kinetic resolution of the corresponding $\mathrm{Ni}(\mathrm{II})$ complexes [62].

First, they investigated the reaction time with racemic valine as a model substrate via dynamic kinetic/thermodynamic resolution in the presence of $\mathrm{K}_{2} \mathrm{CO}_{3}$. Moderate degree (69\%) of deuteration was observed for the ligand 19 after $24 \mathrm{~h}$, while $96 \%$ deuteration degree was found for the Soloshonok ligand 16 after $20 \mathrm{~h}$ and $95 \%$ degree was found for the ligand 1 after $24 \mathrm{~h}$. Then, the optimized ligand 16 was used for the preparation of $\alpha$-deuterated Phe-derived Ni complex under the standard conditions. Both the racemic and (S)-Phe worked very well in the corresponding $(S)(S)$-26 in excellent diastereoselectivity and high deuteration degree (98.8\% d.e., $96 \%$ D). It should be mentioned that further treatment of $(S)(S)-\mathbf{2 6}$ by NaOMe/MeOH$-d_{4}$ under reflux for $2 \mathrm{~h}$ could result in the nearly complete deuteration product (99\% D) (Scheme 6).<smiles>O=C(c1ccccc1)c1cc(Cl)ccc1NC(=O)[C@@H]1CCCN1Cc1ccc(Cl)c(Cl)c1</smiles>

$(S)-16$
1) Phe (1.1 equiv), $\mathrm{NiCl}_{2}$ (1.1 equiv) $\mathrm{K}_{2} \mathrm{CO}_{3}$ (4.0 equiv) $\mathrm{MeOH}-\mathrm{d}_{4}$, reflux, $24 \mathrm{~h}$

2) $\mathrm{AcOH}, \mathrm{H}_{2} \mathrm{O}, 0^{\circ} \mathrm{C}, 1 \mathrm{~h}$

(S)-Phe

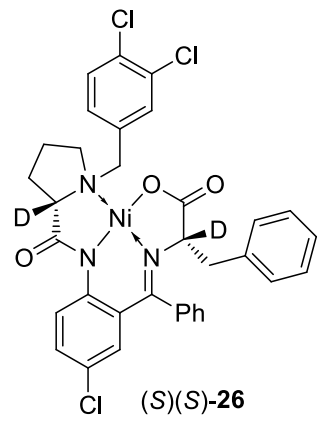

$98.8 \%$ de, $96 \%$ D

$98.8 \%$ de, $96 \%$ D

Scheme 6. Dynamic kinetic/thermodynamic resolution of phenylalanine with concurrent deuteration using ligand (S)-16.

Besides phenylalanine, five other AAs, including valine, leucine, tryptophan, $p$-chlorophenylalanine and 2-(naphthyl)alanine, were tried as the substrates under the standard conditions (Scheme 7). As shown in Scheme 7, all five of these reactions gave excellent results with uniformly excellent yields (87-95\%), diastereoselectivity (95-99\%) and degree of deuteration (84-97\%). All of these results indicate that this reaction provides an efficient and convenient way to $\alpha$-deuterated AAs. 




Scheme 7. Preparation of complex $(S)(S)-27$.

\section{Alkyl Halide Alkylations}

In 2019, Han and co-workers disclosed a facile and efficient protocol for the synthesis of (S)-2-amino-4,4,4-trifluorobutanoic acid (Scheme 8) [63]. This strategy contains three steps without any purification of the intermediates. The first step is the alkylation of the chiral Ni complex (S)-18 via the nucleophilic substitution with 1.1 equivalent of trifluoroethyl iodide in DMF at room temperature.



$(S)-18$



$(S, 2 S)-28$

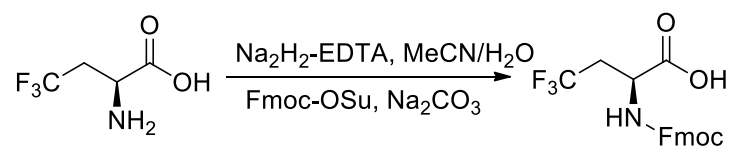



$(S)-16$

(S)-29

(S)-30

Scheme 8. Synthesis of (S)-2-amino-4,4,4-trifluorobutanoic acid.

The intermediate $(S, 2 S)-28$ was obtained in good yield accompanied by minor byproducts such as bis-alkylated product and decomposition of the starting material (S)-18. The disassembly of the nickel complex $(S, 2 S)-28$ was carried out in the presence of $3 \mathrm{~N}$ aqueous $\mathrm{HCl}$ at $60^{\circ} \mathrm{C}$. This transformation could easily be monitored by checking the color. Disappearance of the typical red-orange color demonstrates the accomplishment of the disassembly. The final step is the protection of the free amino group. After chelating the $\mathrm{Ni}$ (II) ions by ethylene diamine tetraacetic acid (EDTA) and treating the 
system with 9-fluorenylmethyl $\mathrm{N}$-succinimidyl carbonate (Fmoc-OSu), $\mathrm{N}$-Fmoc protected amino acid derivative (S)-30 was formed with 74\% yield, which could be easily purified by crystallization leading to $98.6 \%$ chemical purity and $97.8 \%$ ee.

Then, the workers continued their studies to use the procedure for large-scale synthesis [64]. The target product (S)-30 could successfully be prepared in more than $150 \mathrm{~g}$ scale with good chemical yield and excellent diastereoselectivity. Notably, the stoichiometry of trifluoroethyl iodide was reduced from $10 \%$ to $5 \%$ excess ensuring less chemical cost. Nitrogen was used as atmosphere instead of air in the alkylation process to avoid oxidation byproducts. Furthermore, a two-step quenching of the alkylation mixture with water was used to isolate the generated intermediate $(S, 2 S)-28$ without purification by column chromatography. For disassembly of the alkylation intermediate, a higher concentration of $6 \mathrm{~N}$ aqueous hydrochloride was performed instead of $3 \mathrm{~N}$ to accelerate the transformation. It should be mentioned that after disassembly, the chiral tridentate ligand (S)-16 could be reclaimed and reused for synthesis of the glycine $\mathrm{Ni}(\mathrm{II})$ Schiff base (S)-18 again for many times with only about $5 \%$ loss in each cycle. By employing Fmoc-OSu, the final $N$-Fmoc protected amino acid (S)-30 was obtained up to hundred-gram scale in $80 \%$ yield simply by recrystallization with toluene. This newly developed methodology was proved to be sufficiently practicable and inexpensive for the large-scale synthesis of (S)-2-amino-4,4,4-trifluorobutanoic acid.

Soon after, the same group reported a similar practical alkylation strategy for asymmetric synthesis of N-Fmoc-(S)-6,6,6-trifluoronorleucine (S)-33 (Scheme 9) [65]. The alkylation reaction was proved to prefer homogeneous to phase-transfer catalysis conditions. When employing $\mathrm{NaOH}$ as base and DMSO as a solvent, the alkylation product was obtained in a quite low chemical yield $(<40 \%)$ with noticeable decomposition of the starting material (S)-18. Besides, the concentration of $\mathrm{NaOMe}$ in $\mathrm{MeOH}$ affects the transformation significantly. The expected product could be obtained in a dramatically improved yield $(92 \%)$ and diastereoselectivity $(97: 3 \mathrm{dr}$ ) with the use of $10 \% \mathrm{NaOMe}$ solution in $\mathrm{MeOH}$. The diastereomers $(S, 2 S)-\mathbf{3 1}$ and $(S, 2 R)$-31 could be isolated by column chromatography. Disassembly of the major product $(S, 2 S)-31$ proceeded smoothly under the typical conditions of $3 \mathrm{~N}$ aqueous $\mathrm{HCl}$, generating free amino acid (S)-32 along with the salt of Soloshonok ligand (S)-16 and $\mathrm{Ni}(\mathrm{II})$ ions. The target $N$-Fmoc-(S)-6,6,6-trifluoronorleucine (S)-33 was formed after treatment with Fmoc-OSu and purified by recrystallization in $94 \%$ yield and $99 \%$ ee.

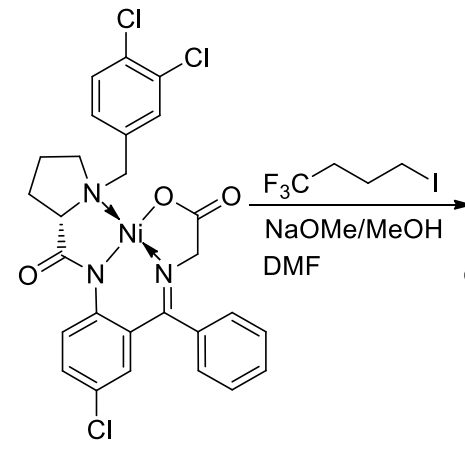

$(S)-18$

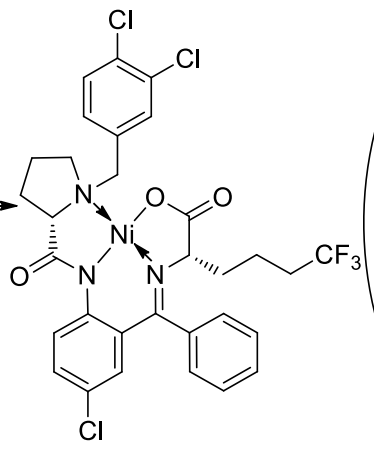

$(S, 2 S)-31$

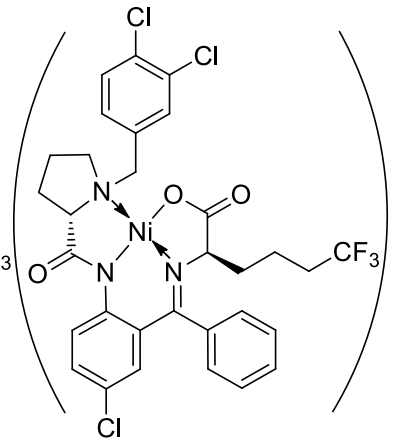

$(S, 2 R)-31$

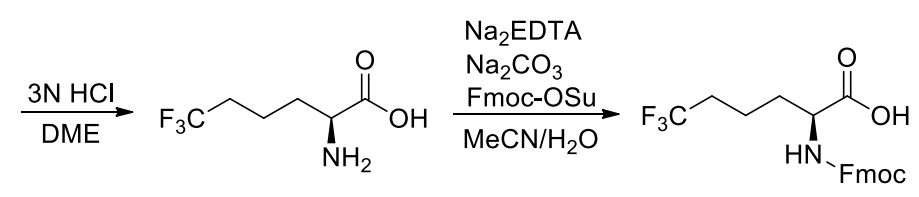

$(S)-32$

(S)-33

Scheme 9. Synthesis of N-Fmoc-(S)-6,6,6-trifluoronorleucine.

Fortunately, this developed route proved tolerable to provide the target $N$-Fmoc-(S)-6,6,6trifluoro-norleucine more than $100 \mathrm{~g}$ in one batch [66]. In this protocol, the chiral ligand (S)-16 
as a precursor of glycine $\mathrm{Ni}(\mathrm{II})$ complex (S)-18 is commercially available and could simply be reclaimed after disassembly. It was recovered quite conveniently by filtration as its hydrochloric salt. The recycled (S)-16 could be reused several times with less than 10\% loss in each cycle. This makes the procedure much more attractive especially for large-scale production. The major diastereomer $(S, 2 S)-31$ could be obtained with excellent yield and diastereomeric purity after addition of water. Treating the alkylation product $(S, 2 S)$-31 under standard disassembly and Fmoc-protection conditions, the target $N$-Fmoc-(S)-6,6,6-trifluoro-norleucine (S)-33 was collected by recrystallization in total $83 \%$ chemical yield and $>99 \%$ enantiomeric selectivity up to $105 \mathrm{~g}$.

Moriwaki, Soloshonok and co-authors prepared (2S)- and (2R)- $\alpha$-(methyl)cysteine derivatives by using the Hamari ligand and Soloshonok ligand [67]. Firstly, using chiral ligand $(R)-\mathbf{1 9}$, the Ni complex $(R)(R / S)-34$ was prepared in the presence of $\mathrm{K}_{2} \mathrm{CO}_{3}$ in $\mathrm{MeOH}$. Then, benzylthiomethylation of $(R)(R / S)$-34 with $\mathrm{NaH}$ as a base was successful for the preparation of the desired products $(R)(R)$ and $(R)(S)-35$ with 76\% yield and 84.3:15.7 diastereoselectivity (Scheme 10). Diastereomerically pure diastereomer $(R)(R)-35$ and $(R)(S)-35$ were obtained by column chromatography in $31 \%$ and $7 \%$ yield respectively.
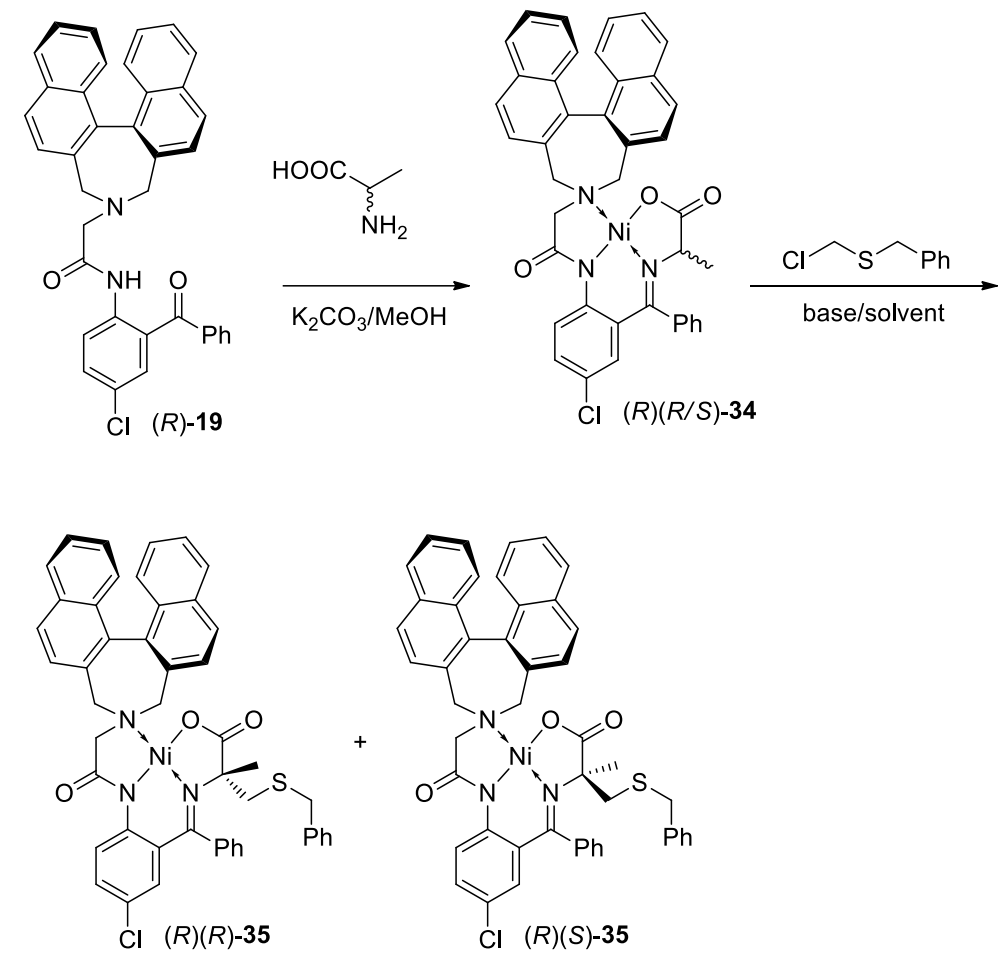

$76 \%$ yield, $84.3: 15.7 \mathrm{dr}$

Scheme 10. Synthesis of $(R)(S)$ - and $(R)(R)$-35 via Hamari ligand.

Then, using another chiral ligand (S)-16 with $\mathrm{NaOH}$ as a base and DMF as a solvent for benzylthiomethylation successfully afforded the desired products $(S)(R)$ - and $(S)(S)-37$ in 77\% isolated yield and 88.9:11.1 dr (Scheme 11). It should be mentioned that improved yield and diastereoselectivity were obtained with the use of Soloshonok ligand (S)-16 for the benzylthiomethylation step. 

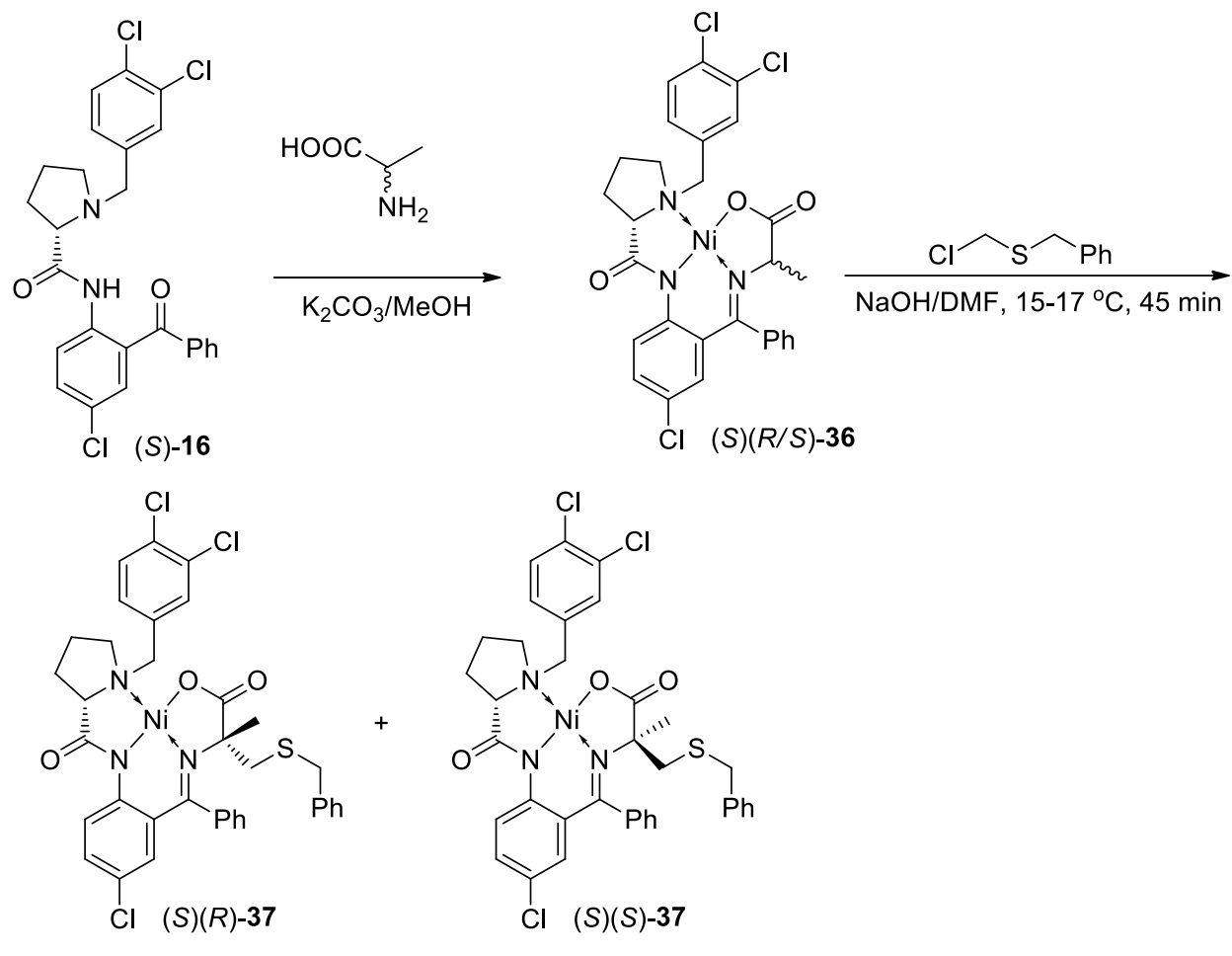

$77 \%$ yield, 88.9:11.1 dr

Scheme 11. Synthesis of $(R)(S)$ - and $(R)(R)-37$ via Soloshonok ligand.

Finally, the chiral amino acid (R)-39 was obtained in a total 38\% yield via the disassembly of the alkylation product $(S)(R)-\mathbf{3 7}$ follow by Boc-protection (Scheme 12). The chiral ligand (S)-16 was also easily recovered in $85 \%$ yield for the next cycle.

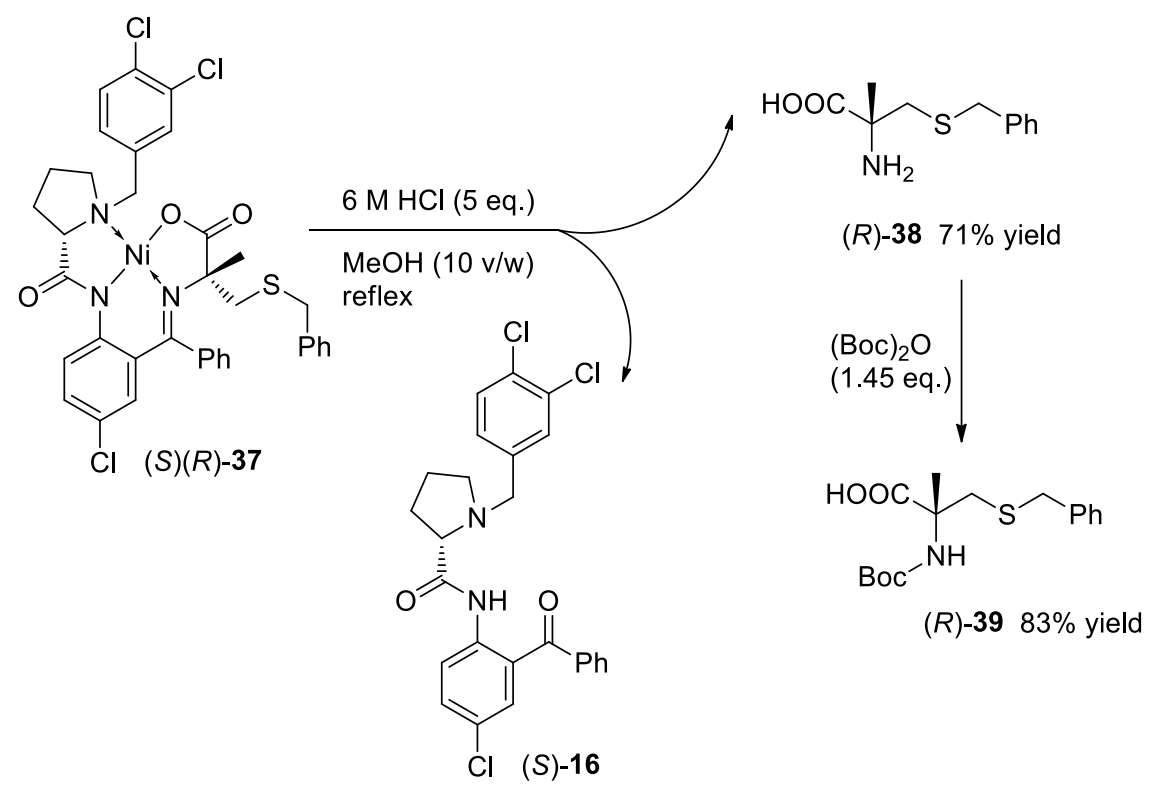

Scheme 12. Synthesis of prepared the chiral amino acid (R)-39.

In 2017, Li and co-authors developed an improved method for the synthesis of the fluorinated chiral ligand 41 from L-proline with a total $90.6 \%$ yield and $>99 \%$ enantioselectivity. Then, they used ligand 41 for the preparation of $\alpha$-dialkenyl and $\alpha$-alkenyl amino acids, which was shown in Scheme 13 [68]. The reaction of ligand 41 with $\mathrm{Ni}\left(\mathrm{NO}_{3}\right)_{2} \cdot 6 \mathrm{H}_{2} \mathrm{O}$ in the presence of $\mathrm{KOH}$ and $\mathrm{MeOH}$ at $65^{\circ} \mathrm{C}$ for $1.5 \mathrm{~h}$ 
afforded the $\mathrm{Ni}$ (II) complexes $\mathbf{4 2 a}$ and $\mathbf{4 2} \mathbf{b}$. The $\mathrm{Ni}(\mathrm{II})$ complexes $\mathbf{4 3} \mathbf{a}$ was obtained in $95 \%$ yield via the reaction of iodoalalkene with $\mathrm{Ni}$ (II) complexes $42 \mathrm{a}$ using $t$-BuONa as a base and DMF as a solvent at room temperature for $0.5 \mathrm{~h}$. The $\mathrm{Ni}(\mathrm{II})$ complexes $43 \mathrm{e}$ and $43 \mathrm{f}$ were obtained with $96 \%$ and $86 \%$ yield under the similar conditions with $\mathrm{NaOH}$ as a base and acetonitrile as a solvent. The desired amino acids 44 were obtained by the disassemble reaction of $\mathrm{Ni}$ (II) complexes $43 \mathrm{a}, 43 \mathrm{e}$ and $43 \mathrm{f}$ in the presence of $\mathrm{HCl}$. Then $\mathrm{N}$-Fmoc protected amino acids 44 were achieved in $72 \%, 66 \%$ and $84 \%$ yield respectively and $>99 \%$ e.e. via treatment by Fmoc-OSu and $\mathrm{Na}_{2} \mathrm{H}_{2} \cdot \mathrm{EDTA}$ in $\mathrm{MeCN} / \mathrm{H}_{2} \mathrm{O}$ for $16 \mathrm{~h}$.

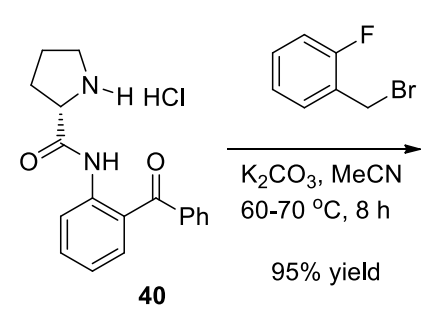

40

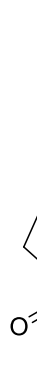<smiles>O=C(Nc1ccccc1C(=O)Nc1ccccc1F)c1ccccc1Cl</smiles>

41

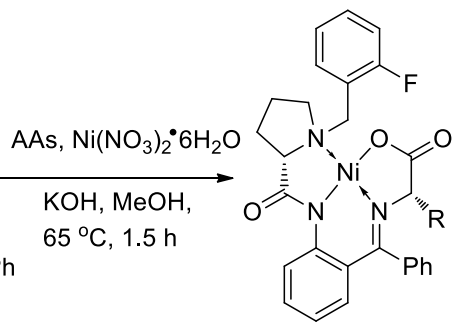

42a $(\mathrm{R}=\mathrm{Me}, 99 \%$ yield $)$ 42b $(R=H, 96 \%$ yield $)$

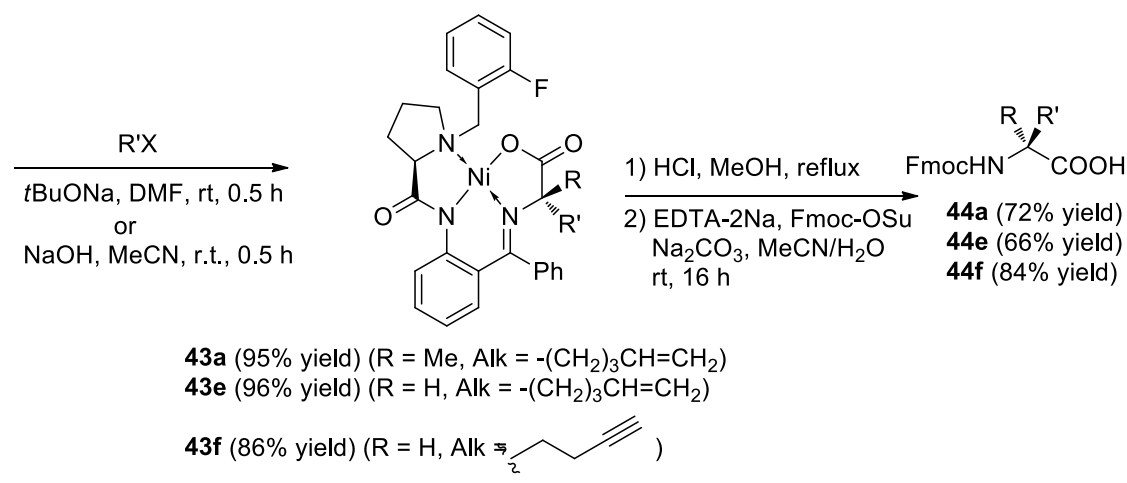

Scheme 13. Synthesis of chiral $\alpha$-substituted amino acids.

Besides the synthesis of chiral $\alpha$-substituted amino acids, the same group also used this alkylation reaction for the synthesis of achiral disubstituted amino acid 47 (Scheme 14). The alkylation of Ni complex 45 with 5-iodo-1-pentene in the presence of base at room temperature provided the Ni complex 46 in $99 \%$ yield. Then, the Fmoc- $\alpha, \alpha$-disubstituted amino acid 48 was obtained in overall $67 \%$ yield via the similar disassembly and protection processes.<smiles></smiles>

45<smiles>C=CCCCCCI</smiles>

$99 \%$ yield<smiles>C=CCCCC1(CCC=C)C(=O)On2n1c(-c1ccccc1)c(-c1ccccc1)n1c3ccccc3c(=O)n21</smiles>

46

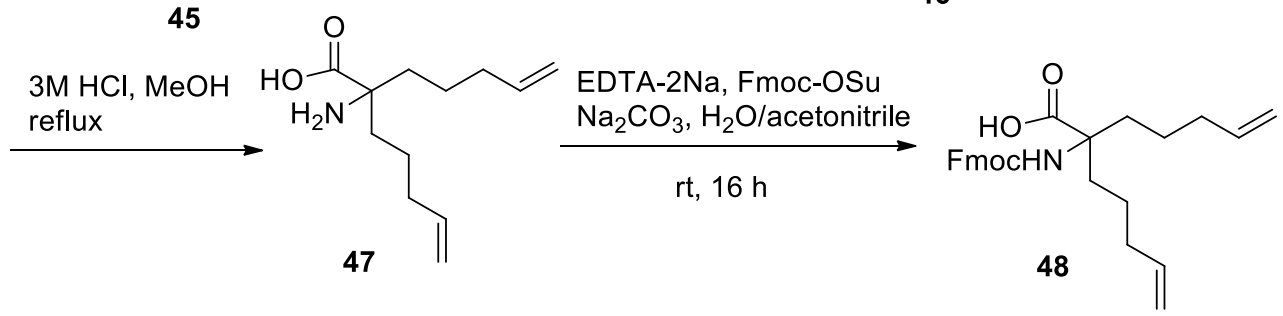

$67 \%$ yield from 46

Scheme 14. Synthesis of $\alpha, \alpha$-disubstituted amino acid. 


\section{Preparation via Second-Order Asymmetric Transformation Control}

The second order asymmetric transformation (SOAT), which is based on labile and interconvertible stereogenic centers, represents another approach for the general synthesis of $\alpha$-AAs. Compared with the regular asymmetric methodology, SOAT is not a common strategy. However, it can be used as an efficient method for the synthesis of AAs concerning operational convenience and scalability.

In 2018, Takeda and co-workers [29] reported an interesting method for the asymmetric synthesis of $\alpha$-amino acids via SOAT approach with the use of highly lipophilic rimantadine [1-(1-adamantyl)ethanamine] derive chiral N-H containing ligand 50. The preparation of chiral ligand $\mathbf{5 0}$ was presented in Scheme 15, which was via two substitution reactions in the presence of $\mathrm{K}_{2} \mathrm{CO}_{3}$ at room temperature with $o$-amino-m-chlorobenzophenone as the starting material.

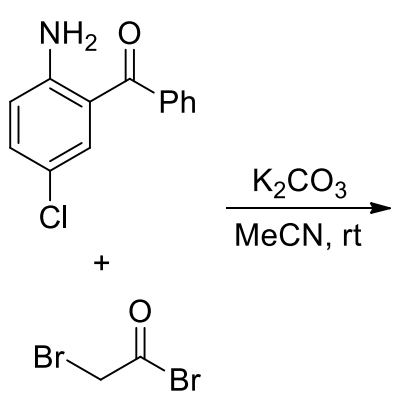<smiles>O=C(CBr)Nc1ccc(Cl)cc1C(=O)c1ccccc1</smiles>

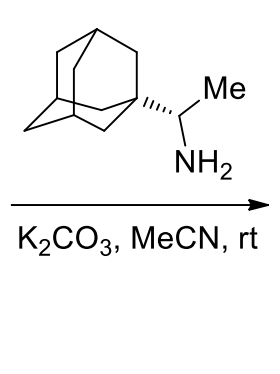<smiles>C[C@H](NCC(=O)Nc1ccc(Cl)cc1C(=O)c1ccccc1)C12CC3C=CC(CC3)C1C2</smiles>

Scheme 15. Synthesis of chiral ligand 50 containing rimantadine group.

Then, this rimantadine-based chiral tridentate ligand $\mathbf{5 0}$ was successfully used in the dynamic kinetic resolution of unprotected racemic AAs under the SOAT conditions. In the presence of $\mathrm{K}_{2} \mathrm{CO}_{3}$, (S)-50, AAs and $\mathrm{Ni}\left(\mathrm{NO}_{3}\right)_{2} \cdot 6 \mathrm{H}_{2} \mathrm{O}$ were stirred in $\mathrm{MeOH}$ at $70{ }^{\circ} \mathrm{C}$ for $2 \mathrm{~h}$. As two new chiral centers generated in this reaction, four diastereomers may be obtained in the reaction mixture. However, diastereomerically pure products, $\left(S_{C}, R_{N}, R_{C}\right)-51$, were observed via gradual formation of crystalline precipitate. The possible reason is that other diastereomers could be converted into $\left(S_{\mathrm{C}}, R_{\mathrm{N}}, R_{\mathrm{C}}\right)-\mathbf{5 1}$ in the presence of base via epimerization at the carbon center and inversion at the nitrogen center. It should be mentioned that this reaction has a wide substrate generality. Varieties of racemic natural AAs and tailor-made AAs, as well as the functional group-containing AAs, participated in this reaction very well, resulting in the corresponding Ni complexes $\mathbf{5 1}$ in 55-99\% yields (Scheme 16).

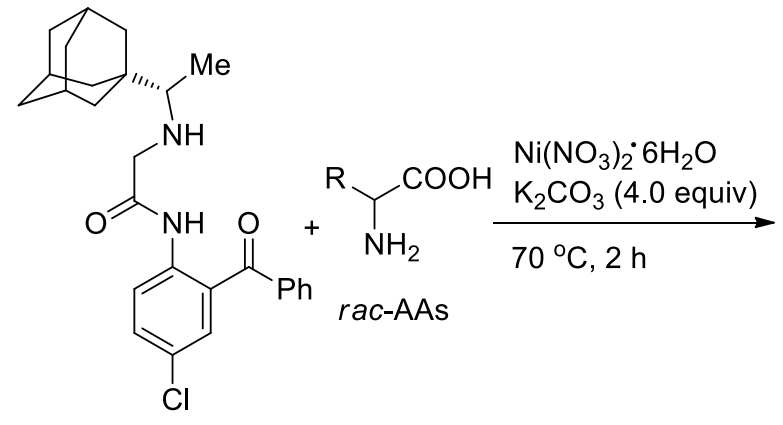

(S)-50

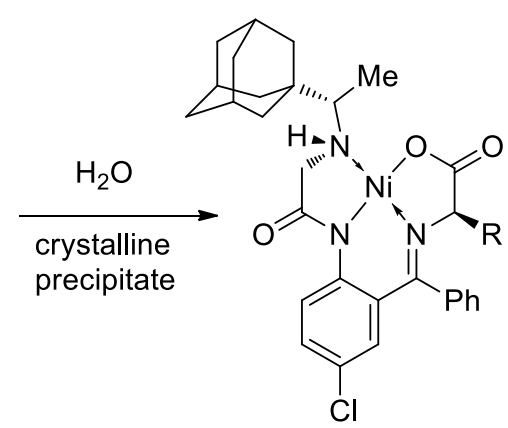

$\left(\left(S_{\mathrm{C}}, R_{\mathrm{N}}, R_{\mathrm{C}}\right)-51 \mathrm{a}-\mathrm{I}\right.$

12 examples, $55->99 \%$ yields

$$
\begin{aligned}
\mathrm{R}= & \mathrm{Ph}, 91 \% \text { yield } \\
& \mathrm{CH}_{3}, 74 \% \text { yield } \\
& i-\mathrm{Bu}, 88 \% \text { yield } \\
& \mathrm{HOCH}_{2}, 55 \% \text { yield }
\end{aligned}
$$

\section{tailor-made AAs}

$$
\mathrm{R}=\mathrm{Pr}, 84 \% \text { yield }
$$

$\mathrm{Bu}$, , 87\% yield

3-bromo-benzyl, 92\% yield

Scheme 16. SOAT approach for the preparation of Ni complexes. 
The disassembly of $\left(S_{\mathrm{C}}, R_{\mathrm{N}}, R_{\mathrm{C}}\right)$-51a was conducted under acidic conditions, which afforded the chiral amino acid hydrochloric salt along with the generation of chiral ligand 50 for the next cycle. Then, the amino acid $(R)-52$ was obtained via cation-exchange chromatography in $83 \%$ yield (Scheme 17).

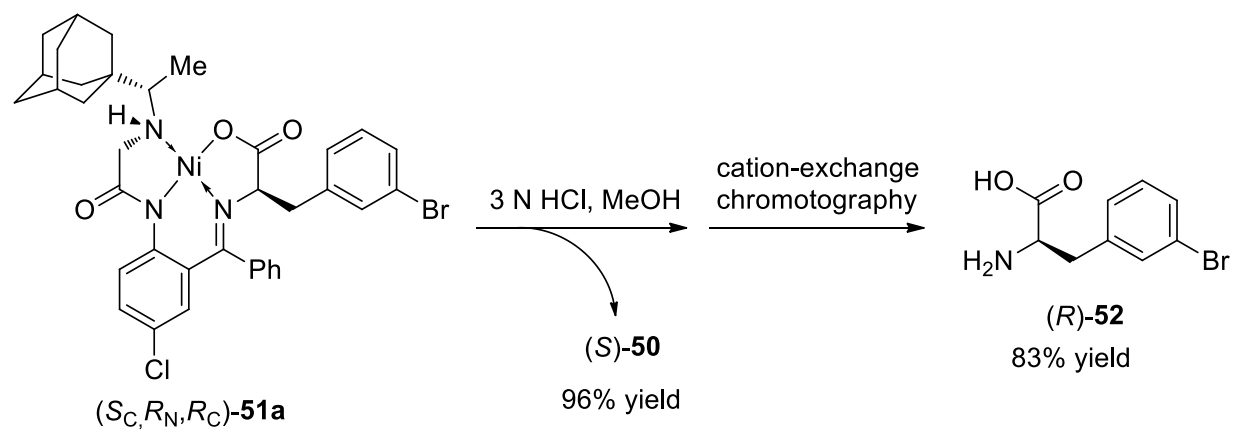

Scheme 17. Disassembly of 51a.

Then, in 2018, the same group further extended this SOAT approach to the synthesis of phenylalanine-type tailor-made $\alpha$-AA (Scheme 18) [69]. First, the Ni complex was prepared via the reaction of ligand 50 with $\mathrm{Ni}\left(\mathrm{NO}_{3}\right)_{2} \cdot 6 \mathrm{H}_{2} \mathrm{O}$ and glycine in the presence of $\mathrm{Na}_{2} \mathrm{CO}_{3}$ and phase-transfer catalyst (PTC), $n$-Bu $\mathrm{Bu}_{4} \mathrm{NI}$. Two diastereomers 53 with the ratio of 3:1 were directly subjected to the alkylation reaction with benzyl bromide with the use of 40 equiv of $30 \% \mathrm{NaOH}$. Four diastereomers, $\left(S_{\mathrm{C}}, R_{\mathrm{N}}, R_{\mathrm{C}}\right)-\mathbf{5 1},\left(S_{\mathrm{C}}, S_{\mathrm{N}}, R_{\mathrm{C}}\right)-51,\left(S_{\mathrm{C}}, R_{\mathrm{N}}, S_{\mathrm{C}}\right)-51$ and $\left(S_{\mathrm{C}}, S_{\mathrm{N}}, S_{\mathrm{C}}\right)-51$ formed in this step. However, the diastereomerically pure products, $\left(S_{C}, R_{N}, R_{C}\right)-51$, was obtained after refluxing in the presence of $\mathrm{K}_{2} \mathrm{CO}_{3}$ in $\mathrm{MeOH}$ for $1 \mathrm{~h}$, stirring at room temperature and crystalline precipitate with the addition of water. Notably, several benzyl bromides containing different substituents, such as trifluoromethyl, bromo, chloro and nitro group were all well tolerated in this reaction in 50-92\% yields.

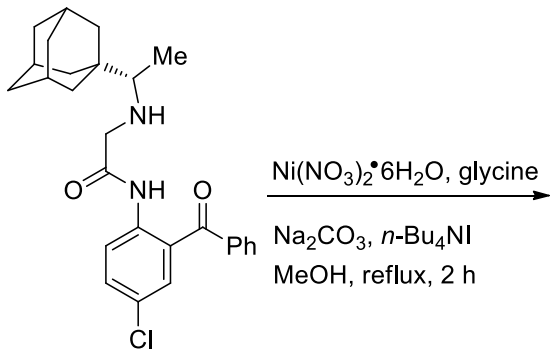

(S)-50<smiles></smiles>

$\left(S_{\mathrm{C}}, R_{\mathrm{N}}\right)-53$<smiles></smiles>

$\left(S_{\mathrm{C}}, S_{\mathrm{N}}\right)-53$


$\left(S_{\mathrm{C}}, R_{\mathrm{N}}, R_{\mathrm{C}}\right)-51$

$4-\mathrm{ClC}_{6} \mathrm{H}_{4}, 50.8 \%$ yield

$4-\mathrm{CF}_{3} \mathrm{C}_{6} \mathrm{H}_{4}, 73.4 \%$ yield

Scheme 18. Synthesis of Ni complexes with glycine derivatives by SOAT. 
The disassembly procedure for $\left(S_{\mathrm{C}}, R_{\mathrm{N}}, R_{\mathrm{C}}\right)$-51a was presented in Scheme 19, which was conducted under similar acidic conditions. After removal of the chiral ligand and treatment of Fmoc-Osu, the Fmoc-amino acid $(R)-54$ were achieved in $99.1 \%$ yield and $97.1 \%$ e.e.

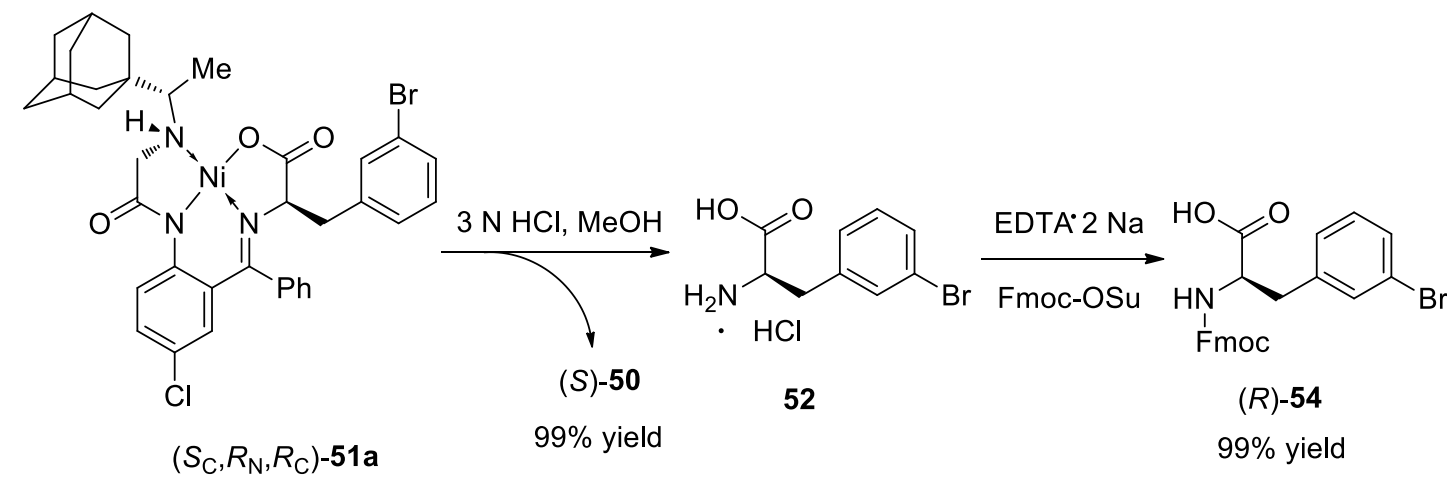

Scheme 19. The disassembly procedure of 51a.

In 2019, Jamieson and co-workers disclosed a new method for the synthesis of $\alpha, \alpha$-disubstituted amino acid derivatives by using chiral tridentate ligand 1 (Scheme 20) [70]. The reaction of alanine with chiral ligand 1 afforded the Ni complex 55 in the presence of powder $\mathrm{KOH}$ with $\mathrm{MeOH}$ as a solvent at $50{ }^{\circ} \mathrm{C}$ for $2 \mathrm{~h}$. The alkylation reaction of Ni complex 55 with 5-iodopentene in the presence of $t \mathrm{BuOK}, n-\mathrm{Bu}_{4} \mathrm{NI}$ as PTC for $16 \mathrm{~h}$ afforded the desired product 56 with $70 \%$ yield and $98 \%$ ee. Product 56 was easy to disassemble in the presence of $\mathrm{HCl}$ at $65{ }^{\circ} \mathrm{C}$ for $3 \mathrm{~h}$. Then, $\mathrm{N}$-Fmoc-protected amino acid 58 was achieved with $49 \%$ yield and $82 \%$ e.e. by using Fmoc-Osu, $\mathrm{Na}_{2} \mathrm{CO}_{3}$ in dioxane/ $\mathrm{H}_{2} \mathrm{O}$ for $16 \mathrm{~h}$. Notably, although good diastereoselectivity was obtained, the decreased enantioselectivity was found in the formation of Fmoc-AAs 58, which is mainly due to the epimerization of the $\alpha$-center of the chiral auxiliary.<smiles>O=C(c1ccccc1)c1ccccc1NC(=O)[C@@H]1CCCN1Cc1ccccc1</smiles>

(S)-1



$\mathrm{MeOH}, 50^{\circ} \mathrm{C}, 2 \mathrm{~h}$.

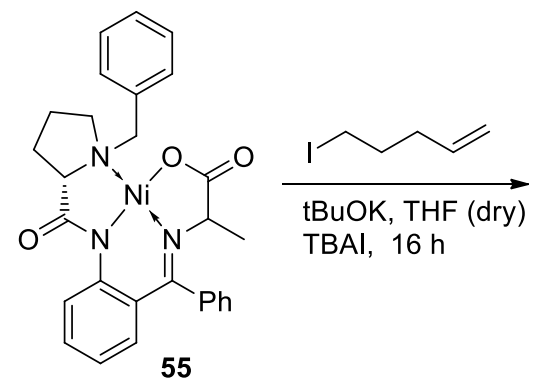<smiles>C=CCCC[C@]1(C)C(=O)O[N+]2(C(=O)N3c4ccccc4C(c4ccccc4)N4CCC[C@H]4C(=O)N32)N1Cc1ccccc1</smiles>

$70 \%$ yield, $98 \%$ de



$80 \%$ yield
$49 \%$ yield, $82 \%$ ee

Scheme 20. Synthesis of $\alpha, \alpha$-disubstituted amino acid derivative.

The authors then optimized their conditions for the step of the formation of complex 55, which mainly focused on the base and reaction time. They used a $\mathrm{KOH}$ solution in $\mathrm{MeOH}$ instead of powder $\mathrm{KOH}$, as well as shorter reaction time for the reaction of ligand $\mathbf{1}$ and alanine (Scheme 21). 
An increased enantioselectivity, as well as a good chemical yield, was obtained when (S)-alanine was used as the starting material ( $92 \%$ e.e. vs $82 \%$ e.e.).<smiles>O=C(c1ccccc1)c1ccccc1NC(=O)C1CCCN1Cc1ccccc1</smiles><smiles></smiles>
$\mathrm{KOH}$ (4.7 M in MeOH)

1

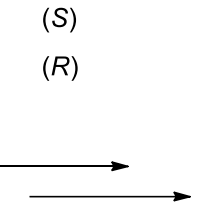

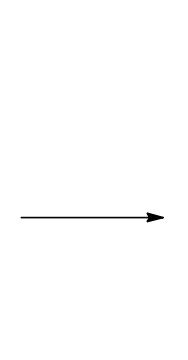

(S, S), $68 \%$ yield, $94 \%$ de
$(R, R), 62 \%$ yield, $92 \%$ de

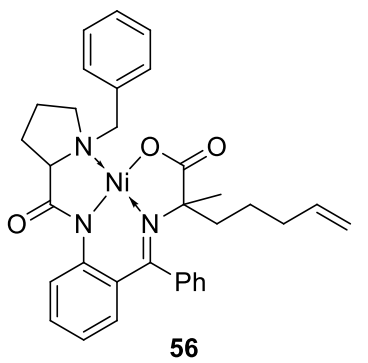<smiles>C=CCCCC(C)(N=C)C(=O)O</smiles>

58
(S), $84 \%$ yield, $92 \%$ ee

(R), $55 \%$ yield, $90 \%$ ee

Scheme 21. An improved synthesis route to $\alpha, \alpha$-disubstituted amino acid derivatives.

In 2019, Jamieson and co-workers successfully used the Ni complex (S)-2 for the preparation of three types of amino acids, which were used in the solid-phase peptide synthesis (SPPS) of histone deacetylases (HDACs) substrate peptidomimetic inhibitors (Scheme 22) [71].<smiles></smiles>

(S)-2

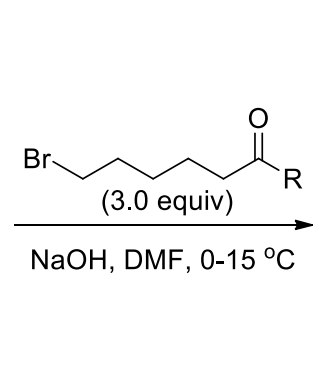

(S)-60

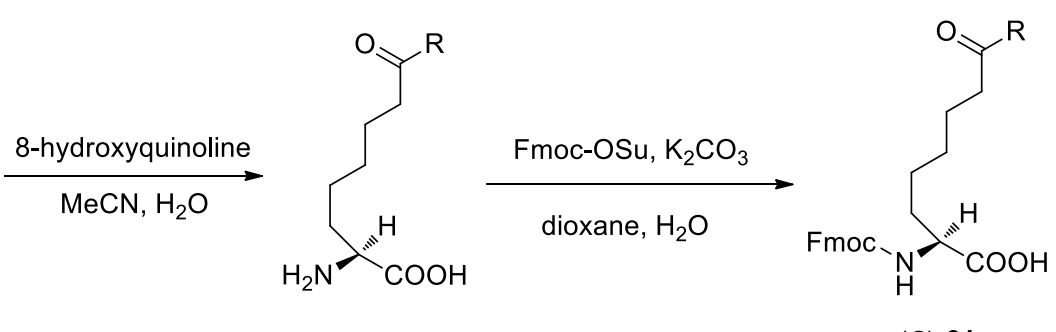

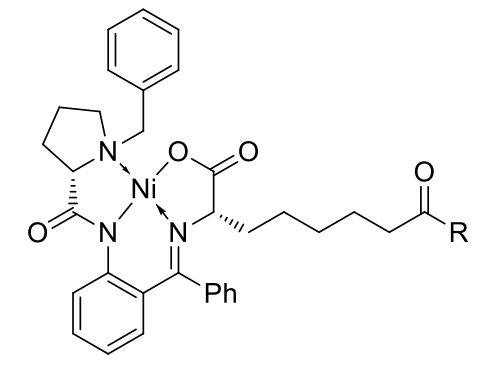

$(S, S)-59$

\footnotetext{
(-

$\mathrm{R}=\mathrm{NHO}{ }^{\dagger} \mathrm{Bu} \quad(S, S)-59 \mathrm{a}, 78 \%$ yied, $88 \%$ de; (S)-60a, 94\% yield; $(S)-61 \mathbf{a}, 98 \%$ yield

$\mathrm{CH}_{3} \quad(S, S)-59 b, 89 \%$ yied; (S)-60b, $94 \%$ yield; (S)-61b, $96 \%$ yield

$\mathrm{CH}_{2} \mathrm{CH}_{3}$ (S,S)-59c, $88 \%$ yied; (S)-60c, 92\% yield; (S)-61c, $98 \%$ yield
}

Scheme 22. Synthesis of Fmoc amino acid 61.

The initial optimization of reaction conditions indicated that the use of 3.0 equiv of alkyl bromide in the presence of sodium hydroxide in DMF at $0-15{ }^{\circ} \mathrm{C}$ provided the best reaction outcomes. The reaction 
of Ni complex (S)-2 with 6-bromo-N-(tert-butoxy)hexanamide afforded the alkylation of product 59a in $78 \%$ yield and $88 \%$ d.e. The disassembly of product 59a afforded the desired amino acid $60 \mathrm{a}$ in $94 \%$ yield via the treatment by 8-hydroxyquinoline in $\mathrm{MeCN} / \mathrm{H}_{2} \mathrm{O}$, which was then converted into Fmoc-L-Asu(NHOtBu)-OH 61a by reacting with Fmoc-OSu in the presence of $\mathrm{K}_{2} \mathrm{CO}_{3}$ and dioxane $/ \mathrm{H}_{2} \mathrm{O}$. Synthesis of amino acids Fmoc-L-Aon-OH $\mathbf{6 1 b}$ and Fmoc-L-Aod-OH 61c was achieved in excellent overall yields and high diastereoselectivities ( $82-84 \%$ d.e.) by using the same route with electrophiles 7-bromoheptan-2-one and 8-bromooctan-3-one as the starting materials.

It should be mentioned that the obtained Fmoc-AAs $\mathbf{6 1}$ were used to synthesize histone tail derived substrate peptidomimetic inhibitor (SPIs) using SPPS strategy, which provided a rapid preparation of the corresponding peptide.

In 2019, enantioselective synthesis of three spin-labeled amino acids $(\mathbf{6 2}, \mathbf{6 3}, \mathbf{6 4})$ (Figure 3) via the Ni complex based strategy was developed by Vederas and co-authors [72].<smiles>CC1(C)C=C(CC(N)C(=O)O)C(C)(C)N1O</smiles>

62

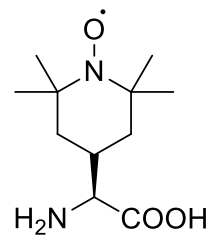

63<smiles>CC1(C)CC(CC(N)C(=O)O)CC(C)(C)N1O</smiles>

64

Figure 3. Structure of three spin-labeled target amino acids (62-64).

The synthesis of spin-labeled amino acids 62 started from the alkylation reaction between Belokon complex 1 and 2,2,6,6-tetramethyl-4-piperidinone derived bromide 66 . The Ni complex $\mathbf{6 5}$ was obtained in $82 \%$ yield, which was converted into the desired amino acid 62 under acidic conditions with $69 \%$ yield and $80 \%$ e.e. (Scheme 23).<smiles></smiles>

$(S)-1$

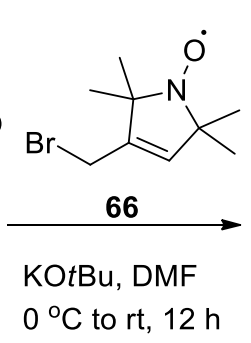

$82 \%$ yield

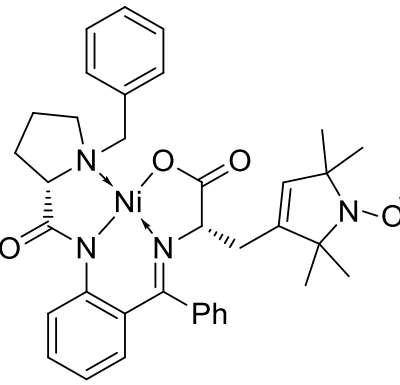

$(S, S)-65$

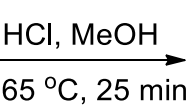<smiles>CC1(C)C=C(CC(N)C(=O)O)C(C)(C)N1[O]</smiles>

$(S)-62$

$69 \%$ yield, $90: 10$ er

Scheme 23. Synthesis of the spin-labeled amino acid 62 .

The authors also tried to apply this alkylation strategy in the preparation of the spin-labeled amino acids 63 and 64. The results disclosed that the direct alkylation onto the Belokon complex was not successful. Thus, in this report, they used a different method, dynamic kinetic resolution (DKR) for the synthesis of spin-labeled amino acids 63 and 64 (Scheme 24). Then, they used racemic amino acids 67 to react with chiral ligand 16 and $\mathrm{Ni}(\mathrm{OAc})_{2}$ affording Ni complexes $(S, S)-\mathbf{6 8}$ or $\mathbf{6 9}$ in the presence of $\mathrm{K}_{2} \mathrm{CO}_{3}$ in $\mathrm{MeOH}$ at $60{ }^{\circ} \mathrm{C}$ for 24 to $48 \mathrm{~h}$ with $95 \%$ and $97 \%$ yield respectively. Finally, the chiral spin-labeled amino acids 63 and 64 were obtained with quantitative, 97\% yield and 90:10, 78:22 e.e., respectively after the disassembly of Ni complex 68 or 69 in the presence of $\mathrm{H}_{2} \mathrm{~N}-\mathrm{OH} \cdot \mathrm{HCl}$ and pyridine at $60{ }^{\circ} \mathrm{C}$ for $20 \mathrm{~h}$. 
<smiles>O=C(c1ccccc1)c1cc(Cl)ccc1NC(=O)[C@@H]1CCCN1Cc1ccc(Cl)c(Cl)c1</smiles>

$(S)-16$

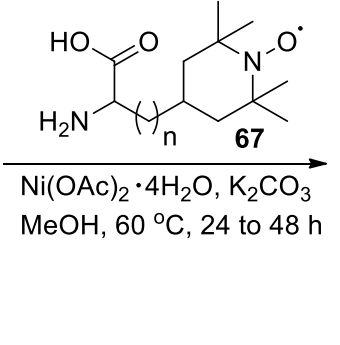

$\underset{\text { pyridine, } 60^{\circ} \mathrm{C}, 20 \mathrm{~h}}{\stackrel{\mathrm{H}_{2} \mathrm{NOH} \cdot \mathrm{HCl}}{\longrightarrow}}$

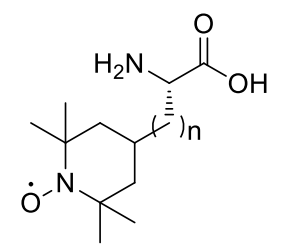

(S)-63 ( $\mathrm{n}=0$, Quant, 90:10 er)

(S)-64 $(n=1,97 \%$ yield, 78:22 er)

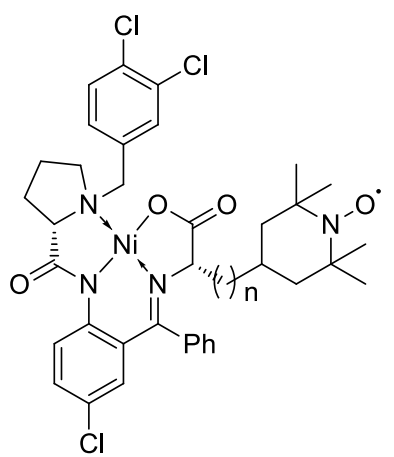

$(S, S)-68(n=0,95 \%$ yield $)$ $(S, S)-69(n=1,97 \%$ yield $)$

Scheme 24. Synthesis of chiral spin-labeled amino acids 63 and 64 .

\section{Addition Reactions}

Asymmetric 1,6-conjugate addition reaction of $\mathrm{Ni}(\mathrm{II})$ complex of glycine with para-quinone methides is the simplest method to achieve the enantiomerically pure tailor-made $\beta, \beta$-diaryl substituted glycines [73].

Recently, a convenient method for the asymmetric synthesis of tailor-made $\beta, \beta$-diaryl substituted glycine derivatives was developed (Scheme 25). Initially, they used the chiral Ni(II) complex 2 of glycine and ketone 70a as model substrates to optimize the asymmetric 1,6-conjugate reaction conditions. The absolute configuration of the obtained major diastereomer complex $\mathbf{7 1}$ was determined as $(2 S, 3 S)$ by $\mathrm{X}$-ray structural analysis. The highest chemical yield and good diastereoselectivity were observed when sodium hydride $(\mathrm{NaH})$ was served as the base in $\mathrm{CH}_{2} \mathrm{Cl}_{2}$ (chemical yield $80 \%$, d.e. $=98 \%$ ). Then, asymmetric 1,6-conjugate addition reaction of $\mathrm{Ni}$ (II) complex to different para-quinone methides was investigated. Both electron-donating and electron-withdrawing substituents, such as methyl, methoxy, halogen, and nitro groups, were well tolerated in this asymmetric addition reaction affording the corresponding products in moderate to good yields (59-80\%) and excellent diastereoselectivities (up to $99 \%$ ).

Liu and co-authors [74] reported an asymmetric Michael addition of $\mathrm{Ni}(\mathrm{II})$ complex 2 with $\beta$-trifluoromethylated- $\alpha, \beta$-unsaturated ketones for the synthesis of chiral trifluoromethyl containing heterocyclic amino acids. In this asymmetric Michael addition, major diastereomer $(S)(2 S, 3 S)-73$ was obtained along with other three diastereomers. After careful optimization of reaction conditions, it was found that the use of $\mathrm{DBU}$ in $\mathrm{CH}_{2} \mathrm{Cl}_{2}$ at room temperature provided the highest yield $(78 \%)$ and diastereoselectivity $(\mathrm{dr}=15 / 85 / 0 / 0)$. Then, various $\beta$-trifluoromethylated- $\alpha, \beta$-unsaturated were screened (Scheme 26). $\beta$-Trifluoromethylated- $\alpha, \beta$-unsaturated ketones with aryl group effectively participated in the reaction well achieving moderate chemical yields (54-78\%). Moreover, fused ring and heteroaromatic ring substrates were also applicable, giving the expected products 73 with good results (68-78\% yields). Remarkably, the presence of the furyl ring enhanced both the reactivity and diastereoselectivity (0/96/4/0 d.r. and $78 \%$ yield). 
<smiles>[3H]C=C1C=C(C(C)(C)C)C(=O)C(C(C)(C)C)=C1</smiles>

(S)-2

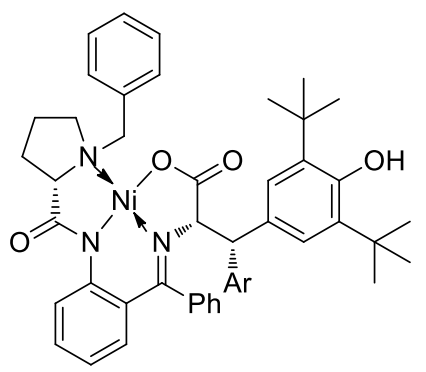

$(S)(2 S, 3 S)-71 \mathrm{a}-\mathrm{I}$

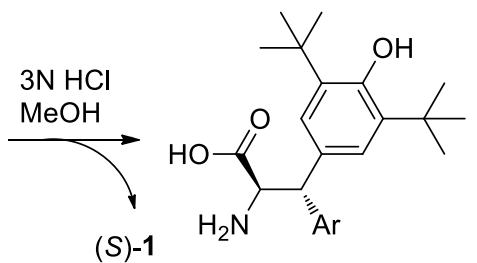

72 71a, $\mathrm{Ar}=\mathrm{Ph}, 80 \%$ yield, de $98 \%$

71b, $\mathrm{Ar}=2-\mathrm{Me}-\mathrm{Ph}, 59 \%$ yield, de $98 \%$

71c, $\mathrm{Ar}=4-\mathrm{Me}-\mathrm{Ph}, 60 \%$ yield, de $>99 \%$

71d, $\mathrm{Ar}=4-\mathrm{F}-\mathrm{Ph}, 67 \%$ yield, de $96 \%$

71e, $\mathrm{Ar}=4-\mathrm{Cl}-\mathrm{Ph}, 72 \%$ yield, de $>99 \%$

71f, $\mathrm{Ar}=4-\mathrm{Br}-\mathrm{Ph}, 63 \%$ yield, de $>99 \%$

71g, $\mathrm{Ar}=4-\mathrm{CF}_{3}-\mathrm{Ph}, 70 \%$ yield, de $>98 \%$ 71h, $\mathrm{Ar}=4-\mathrm{CN}-\mathrm{Ph}, 70 \%$ yield, de $>99 \%$

71i, $\mathrm{Ar}=4-\mathrm{NO}_{2}-\mathrm{Ph}, 73 \%$ yield, de $>99 \%$

71j, $\mathrm{Ar}=4-\mathrm{MeO}-\mathrm{Ph}, 67 \%$ yield, de $>99 \%$

$71 \mathrm{k}, \mathrm{Ar}=$ naphthyl, $50 \%$ yield, de $>99 \%$

71I, $\mathrm{Ar}=$ thiophene, $34 \%$ yield, de $94 \%$

$72 \mathrm{a}, \mathrm{Ar}=\mathrm{Ph}, 86 \%$ yield, ee $98 \%$

72f, $\mathrm{Ar}=4-\mathrm{Br}-\mathrm{Ph}, 85 \%$ yield, ee $98 \%$

72j, $\mathrm{Ar}=4-\mathrm{MeO}-\mathrm{Ph}, 91 \%$ yield, ee $>94 \%$

Scheme 25. Asymmetric 1,6-conjugate addition reaction of $\mathrm{Ni}(\mathrm{II})$ complex 2.<smiles></smiles>

$(S)-2$<smiles>[R]C(=O)/C=C\C(=O)OCC</smiles>
$R^{3}$

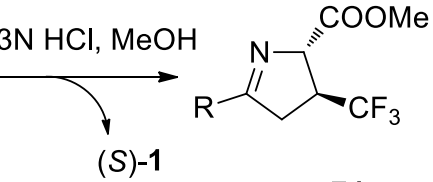

$(2 S, 3 S)-74$

$\mathrm{R}=\mathrm{Ph}, 66 \%$ yield, $94 \%$ ee 2-furyl, 68 yield, $93 \%$ ee

Scheme 26. Asymmetric Michael addition of Ni(II) complex 2 with $\beta$-trifluoromethylated$\alpha, \beta$-unsaturated ketones.

Decomposition of diastereomerically pure $(S)(2 S, 3 S)-73$ was conducted under the standard conditions by heating a suspension of complexes in $\mathrm{MeOH}$, using $1 \mathrm{~mol} / \mathrm{L}$ hydrochloric acid, which afforded the target amino acids (2S,3S)-74 in high enantioselectivities (Scheme 26). The amino acid $(2 S, 3 S)-74 \mathbf{a}$ was further converted into trifluoromethylated proline derivative $(2 S, 3 S, 5 S)-75 \mathbf{a}$ via $\mathrm{Pt}_{2} \mathrm{O}$-promoted hydrogenation (Scheme 27).

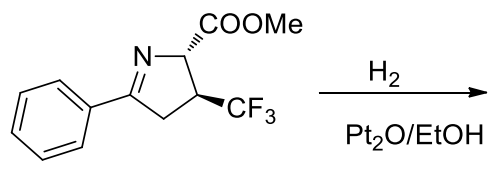

$(2 S, 3 S)-74 a$<smiles>COC(=O)[C@H]1NC(c2ccccc2)C[C@H]1C(F)(F)F</smiles>

(2S, 3S, 5S)-75a, $94 \%$ yield, $94 \%$ de

Scheme 27. Reduction of $(2 S, 3 S)-74 a$.

Magdesieva and co-authors [75] reported the first example of regio- and stereoselective electrosynthesis of the protected primary fulleroamino acid with double chirality (Scheme 28). Compounds (77a and 77b) have three chiral centers in the addend (including the stereogenic $\alpha$-amino-acid carbon center directly bound to the fullerene) and the fullerene cage itself exhibits 
a non-inherently chiral 1,4-functionalization pattern. Diastereo- and enantiomerically pure $\left({ }^{\mathrm{f}, \mathrm{t}} \mathrm{A}\right)$ and $\left({ }^{\mathrm{f}, \mathrm{t}} \mathrm{C}\right)-1,4$-fulleroamino acid derivatives were isolated and fully characterized. Electrochemical deprotonation of (S)-2 was performed with azobenzene radical-anions (at the potential of their formation, $-1.32 \mathrm{~V}$ vs. $\mathrm{Ag} / \mathrm{AgCl} / \mathrm{KCl})$. After complete deprotonation of $(S)-\mathbf{2}, \mathrm{C}_{60}$ was added to generate the carbanionic fullerene intermediate $\mathbf{7 6}$, which underwent consecutive $\mathrm{S}_{\mathrm{N}} 2$ reaction with allyl or benzyl bromides.

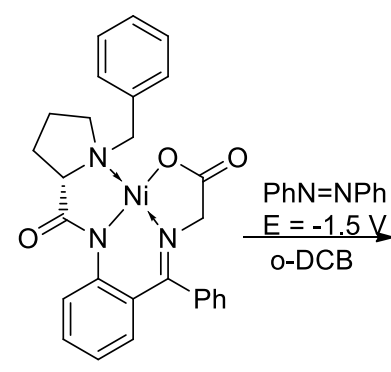

$(S)-2$
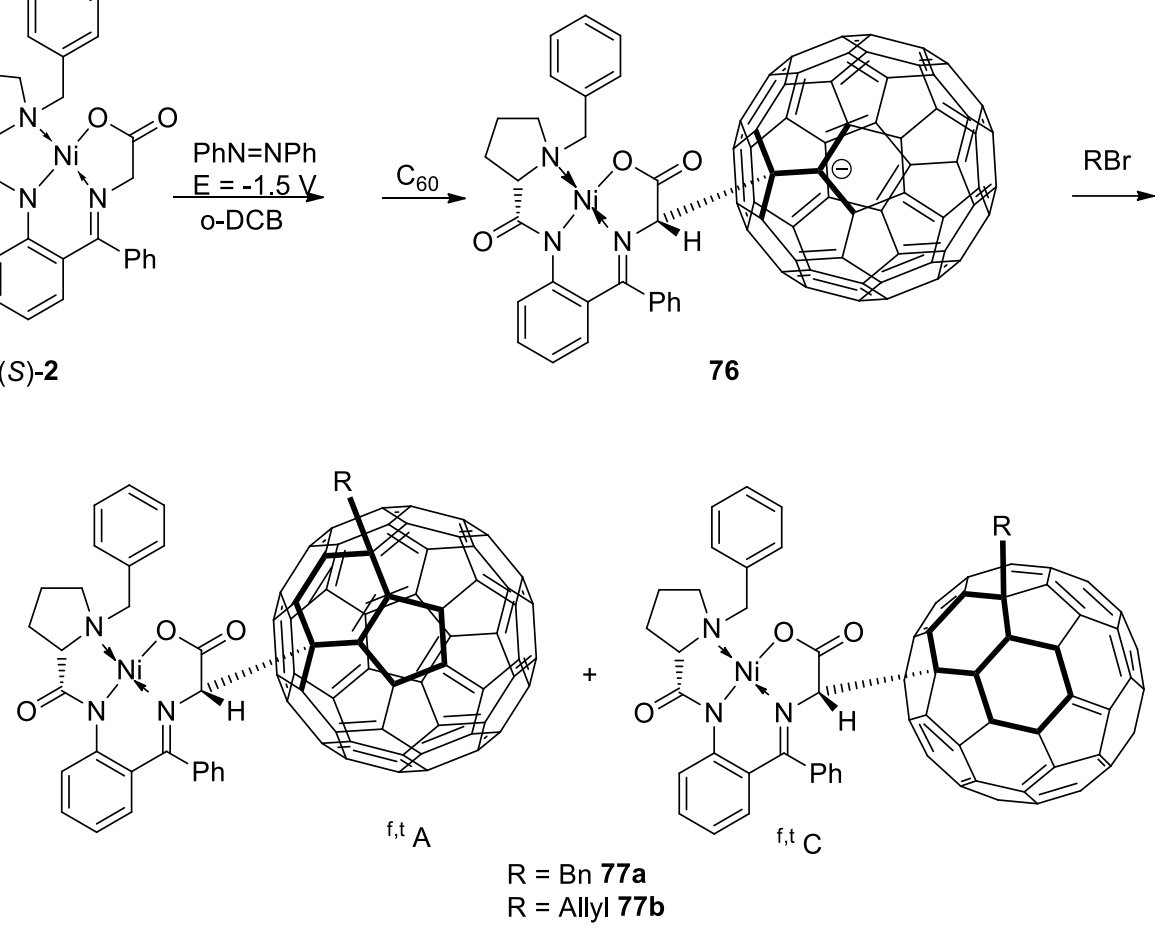

Scheme 28. Synthesis of complexes $77 \mathbf{a}$ and $77 \mathbf{b}$.

It was found that deprotonated (S)-2 and the alkyl group are attached to the fullerene cage in both isomers. The isomer ratio was 1.5:1 for the allyl and 2:1 for the benzyl auxiliary addend, and the chemical yields were $37 \%$ and $40 \%$, respectively. Preferable formation of the 1,4-adduct was seen from the DFT calculated HOMO of the anionic intermediate formed after the nucleophilic addition of deprotonated (S)-2 to $\mathrm{C}_{60}$. Based on the calculation and experimental CD spectra of the 1,4-regioisomers, the authors concluded that the major stereoisomer has the $\left(S, S,{ }^{\mathrm{f}, \mathrm{t}} \mathrm{C}\right)$ absolute configuration whereas its minor counterpart has the $\left(S, S,{ }^{\mathrm{f}, \mathrm{t}} \mathrm{A}\right)$ configuration. A voltammetric study of the $\left(\mathrm{S}, \mathrm{S},{ }^{\mathrm{f}, \mathrm{t}} \mathrm{C}\right)-\mathbf{7 7}$ a stereoisomer showed a superposition of $(S)-\mathbf{2}$ and $\mathrm{C}_{60}$ redox activity [75].

Larionov et al. [76] reported a selective $N$-functionalization of indoles via Michael addition of indole to chiral Ni(II) Schiff base complex 78 (Scheme 29). Ni(II) complex of the Schiff base of dehydroalanine (S)-78 and indole were chosen as the model substrates to optimize reaction conditions. Good chemical yield $(80 \%)$ was observed when $\mathrm{NaH}$ was used as the base. It was shown that indoles with electron-withdrawing substituents furnished the products 79 in moderate to good yields (55-81\%). Indoles with electron-donating groups furnished the products 80 in good yields of $80 \%$ and $82 \%$ (Scheme 29). 
<smiles>C=C1C(=O)O[N+]23N(C1=O)C(=C(c1ccccc1)c1ccccc1)c1ccccc1N2C(=O)[C@@H]1CCCN13</smiles>

$(S)-78$<smiles>[R]Cc1ccccc1-n1ccc2ccccc21</smiles>

$(S, S)-79$

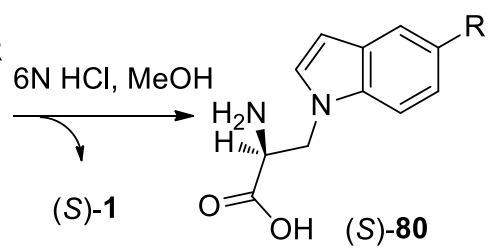

$\mathrm{R}=\mathrm{H}, 80 \%$ yield, $>99$ ee $\mathrm{R}=\mathrm{OMe}, 65 \%$ yield

Scheme 29. Asymmetric aza-Michael addition of indoles.

DFT calculations helped to rationalize the observed N1-alkylation of the indoles over the non-observed C3-alkylation. DFT calculations results show that the top-side attack by nitrogen atom is the most favorable due to the absence of steric clashes with the benzyl group in the proline fragment. The authors concluded that the top-side attack by nitrogen atom is the most favorable leading to the desired product.

Fluorine-containing amino acids are of growing importance in drug discovery and peptide chemistry $[5,77,78]$. Although a variety of synthetic methods of $\gamma$-fluorinated analogs of glutamic acid and glutamine were reported [79-81], there were many problematic issues such as multi-step reaction sequences and synthetically unattractive stereochemical outcome. Therefore, Michael-type addition reaction of $\mathrm{Ni}$ (II) complex of dehydroalanine Schiff base 81 [82] and ethyl bromodifluoroacetate in the presence of copper for the synthesis of racemic 4,4-difluoroglutamic acid derivative were investigated. These reactions proceeded smoothly and gave the desired product 82 in $80 \%$ yield. By the disassembly of $\mathrm{Ni}$ (II) complex and $\mathrm{N}$-protection, racemic Cbz-4,4-difluoro glutamic acid 83 was obtained in three steps from known compounds [83] (Scheme 30).

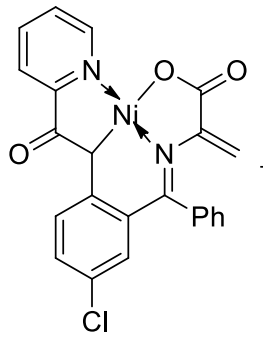

81<smiles></smiles>

1) $6 \mathrm{M} \mathrm{HCl} / \mathrm{THF}$

2) $\mathrm{CbzCl}, \mathrm{EDTA}$ $60 \%$<smiles></smiles>

83

Scheme 30. Michael-type addition reaction between achiral complex of dehydroalanine and ethyl bromodifluoroacetate.

Based on the above results, four chiral Ni(II) complexes of dehydroalanine Schiff base were prepared and reacted with ethyl bromodifluoroacetate in the presence of copper to yield enantiomerically enriched Cbz-4,4-difluoro glutamic acid (S)-83 [84]. As a result, it was found that the diastereoselectivity of this Michael-type addition reaction depends on the chlorine substitutions on the starting $\mathrm{Ni}$ (II) complexes and the Soloshonok ligand-derived trichloro-substituted Ni(II) complex of a dehydroalanine Schiff base (S)-84d afforded an attractive value of $>$ 98:2 diastereomeric ratio (Scheme 31). 


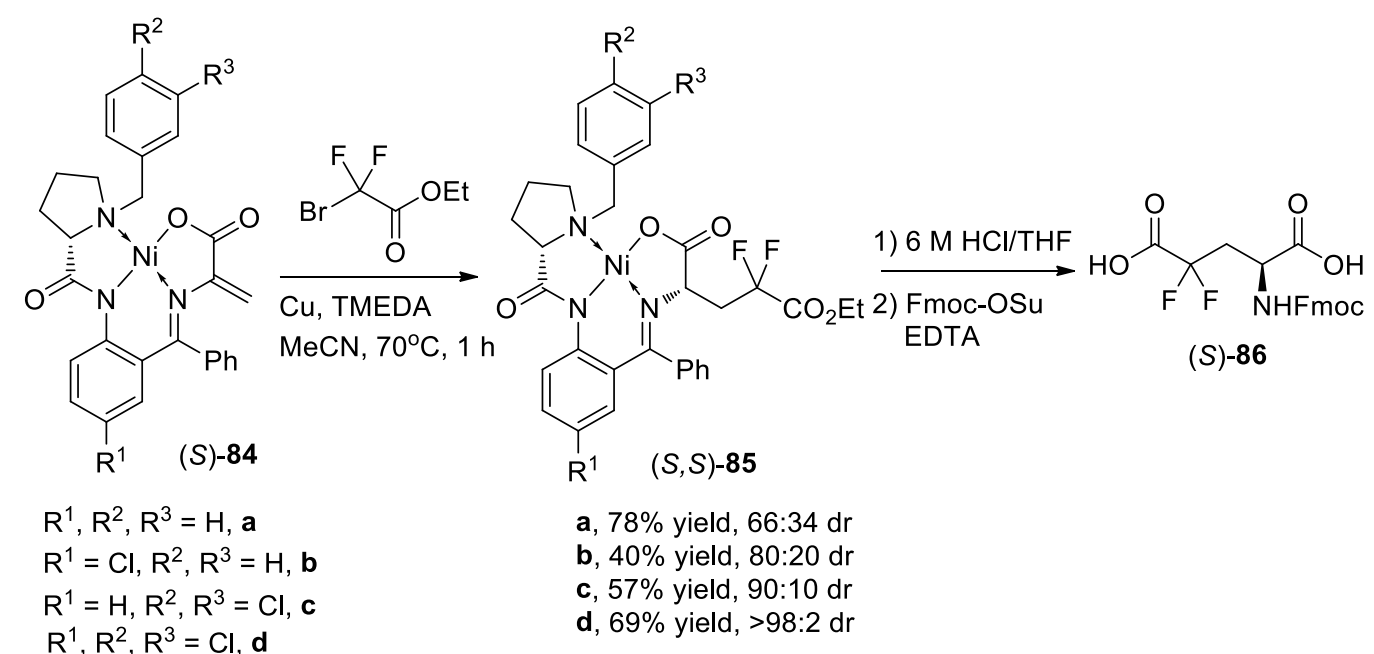

Scheme 31. Asymmetric synthesis of difluoroglutamic acid derivative (S)-86 via Michael-type addition reaction between chiral complex (S)-84 and ethyl bromodifluoroacetate.

Practical new routes for the preparation of optical active 3-Me-glutamine derivatives were described using Michael addition reaction of $\mathrm{Ni}(\mathrm{II})$ complex of chiral Gly-Schiff base (S)-18 (Scheme 32). These derivatives are classified as conformationally constrained tailor-made AAs and are found in several unique peptidyl natural products [85-87]. In particular, 3-Me-glutamine residue is a structural part of callipeltins $\mathrm{O}$ and $\mathrm{Q}$ isolated from a marine sponge [88]. Michael additions of (S)-Gly-Schiff base $\mathrm{Ni}$ (II) complexes of type $\mathbf{1 8}$ provide a reliable access to -substituted glutamic acid derivatives [46,47,52]. In the recent work, this approach was used for preparation of derivatives $\mathbf{8 9}$ and $\mathbf{9 0}$ needed for the total synthesis of some analogs of natural callipletins [88]. Complex (S)-(2S,3S)-87 was prepared via Michael addition of (S)-Gly-Schiff base 18 and ethyl crotonate (61\% yield and 80\% de). After the disassembly of $\mathrm{Ni}(\mathrm{II})$ complex, followed by the Fmoc protection, target (S)-(2S,3S)-Fmoc-3-MeGlu-OH 89 was isolated in optically pure form. Likewise, $(2 S, 3 S)-\mathrm{Fmoc}-3-\mathrm{MeGlu}(\mathrm{Xan})-\mathrm{OH} 90$ was conveniently synthesized from allyl crotonate via $(S)-(2 S, 3 S)-88$. In this case, several steps to change the protecting groups were needed to prepare the target AA suitable for solid-phase peptide synthesis [89].



Scheme 32. Asymmetric synthesis of optical active 3-Me-glutamine derivatives 89 and 90 via Michael-type addition reaction between chiral complex (S)-18 and crotonate.

\section{Coupling Alkylation}

Tailor-made AA containing biphenyl groups are often used in the polymers, dyes and other compounds [3]. A variety of enantiomerically enriched non-protein (S)- $\alpha$-amino acids with biphenyl 
groups in the side chain based on the Suzuki coupling reaction were obtained (Scheme 33) [90]. This Suzuki coupling reaction showed a wide substrate generality with regard to boronic acid derivatives. In most cases, the reactions furnished the products 92 in moderate to good yields (55-86\%). Relatively high yields were recorded with phenyl- ( $86 \%$ yield) and biphenylboronic ( $83 \%$ yield) acids. The decomposition of complexes 92 and isolation of enantiomerically enriched target amino acids 93 were also carried out. It should be noted that some of amino acids could be crystallized directly from the acid hydrolysate by passing the stage of ion exchange purification (demineralization).

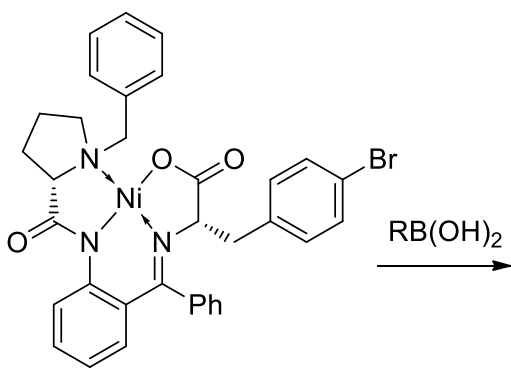

$(S)-91$<smiles></smiles>

(S)-92

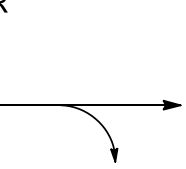

(S)-1

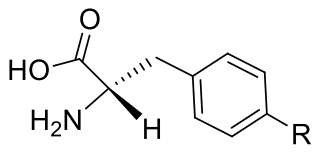

$(S)-93$

$(55-86 \%$ yield $)$

$(76-97 \%$ yield $)$

Scheme 33. Suzuki reaction between (S)-91 and different boric acids.

Tailor-made enantiopure $\alpha$-AAs with $\gamma$-tertiary and quaternary carbon centers display various interesting biological activities [91,92]. Practical new routes for the preparation of these compounds via iron-catalyzed olefin-olefin coupling of dehydroalanine complex $\mathbf{7 8}$ were reported (Scheme 34) [93]. Stirring of $\mathrm{Ni}$ (II) complex 78 with 5 equiv of olefin in the presence of an inexpensive $\mathrm{Fe}(\mathrm{acac})_{3}$ mediator (30 mol\%) and 1.5 equiv of phenylsilane in a mixed solvent of 1,2-dichloroethane (DCE)/EtOH at room temperature furnished product $(S, S)-94 a$ in a $90 \%$ yield $(\mathrm{dr}>20: 1)$. The formation of a by-product $(S)-95$ was also observed with less than $5 \%$ yield. A variety of different olefins reacted very well with $(S)-78$ affording products 94 in good yields (Scheme 34). The reaction also showed good diastereoselectivity, and in all cases the ratio of $(S, S, X)$ to $(S, R, X)$ was more than 15:1. Two gram-scale reactions with $\alpha$-methyl styrene and methyl methyl(vinyl)phosphinate were also performed. The desired products $(S, S)-94$ were isolated via standard silica chromatography in $93 \%$ ( $2.3 \mathrm{~g})$ and $63 \%$ (1.6 g). Authors succeeded to isolate two enantiopure (S)-amino acids in $83 \%$ and $78 \%$ yields, respectively.<smiles>C=C1C(=O)O[N+]2(C(=O)N3c4ccccc4C(c4ccccc4)N4CCC[C@H]4C(=O)N32)N1Cc1ccccc1</smiles>

(S)-78

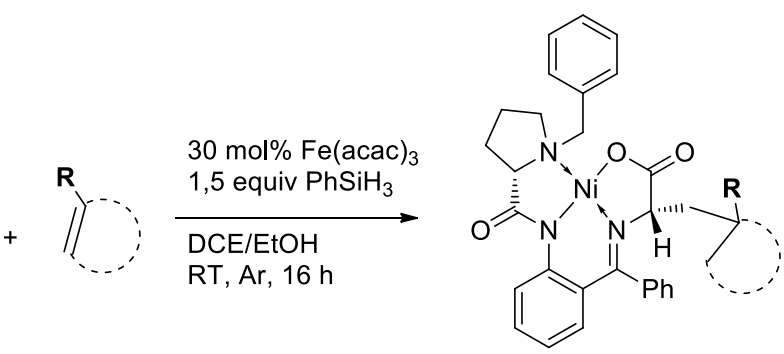

$(S, S)-94$

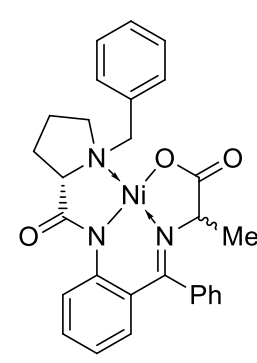

(S)-95

Scheme 34. Fe-catalyzed coupling reaction of Ni complex 78.

A new electrochemical method for stereoselective hydroxyalkylation of (S)-2 was elaborated by Levitskiy and co-authors (Scheme 35) [94]. Galvanostatic electrolysis of (S)-2 was performed in a one-compartment electrochemical cell in alcohol solution in the presence of $\mathrm{KOH}$, which acts as a deprotonating agent and a supporting electrolyte simultaneously. Electrochemical oxidation of the alkoxide anion leads to the corresponding carbonyl compound which reacts with the deprotonated (S)-2 complex. It was found that the stereochemical outcome of the process is depended on the $\mathrm{pH}$ of the solution and the reaction time between the end of the electrolysis and the work-up 
procedure. Thermodynamically more stable (2S)-complex (for $\mathrm{MeOH}$ ) and (2R,3S)-diastereomer (for the homologues) were formed at high $\mathrm{pH}$ with high diastereoselectivity (de up to $94 \%$ ). In the media with low basicity, the (2S) complex (for $\mathrm{MeOH}$ ) and (2S,3R)-diastereomer (for higher alcohols) can be obtained $(\mathrm{de}=100 \%)$.<smiles>O=C1CN2C(c3ccccc3)=C3c4ccccc4N4C(=O)[C@@H]5CCCN5[N+]3(Cc3ccccc3)OC(=O)CN4[N+]2(Cc2ccccc2)C1</smiles>

(S)-2

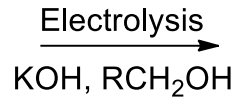
$\mathrm{KOH}, \mathrm{RCH}_{2} \mathrm{OH}$

(1)
.

$(S, S, R)-96$

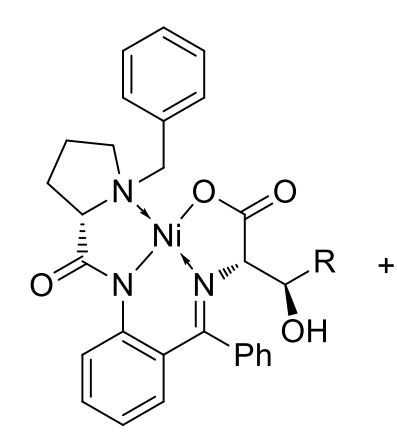

95-97\%<smiles></smiles>

$(S, R, S)-96$

$$
\mathrm{R}=\mathrm{H}(\mathbf{a}) ; \mathrm{CH}_{3}(\mathbf{b}) ; \mathrm{C}_{2} \mathrm{H}_{5}(\mathbf{c}) ;{ }^{i} \mathrm{Bu}(\mathbf{d})
$$

Scheme 35. Electrochemical stereoselective oxyalkylation of the (S)-2.

\section{Dynamic Kinetic Resolution}

Among various types of fluorinated tailor-made AAs, linear $\omega-\mathrm{CF}_{3}-\mathrm{AAs}$ represent a family of structurally relatively simple, yet very useful compounds widely used in drug development and peptide research [95-104]. In particular, (S)-2-amino-5,5,5-trifluoropentanoic acid, a fluorinated analog naturally occurring in bacterial proteins norvaline [105], has been extensively used in the design of bioactive formulations [106-112] and protein research.

In 2019, two alternative approaches were developed for the preparation of (S)-2-amino-5,5,5-trifluoropentanoic acid and its Fmoc-derivative [113]. The authors reported that the alkylation procedure could be successfully performed on a $\sim 1 \mathrm{~g}$ scale, while the dynamic kinetic resolution was generally a more practical solution for scaled-up $(\sim 20 \mathrm{~g})$ synthesis. Based on alkylation $[16,36]$ and kinetic resolution $[31,33]$ approaches, authors used trichloro-substituted ligands for the preparation of the target (S)-2-amino-5,5,5-trifluoropentanoic acid derivatives. In the case of alkylation of glycine complex (S)-18, 1,1,1-trifluoro-3-iodopropane was used as alkylation reagent. It should be mentioned that several byproducts including minor diastereomer $(S)(2 R)-97$, bis-alkylated complex (S)-98, and 4-phenylquinazoline (S)-99, were also observed in these reactions. Application of a base in homogeneous form like $\mathrm{NaOMe}$, solutions, or ground to powder $\mathrm{NaOH}$ led to noticeable decomposition of the alkylation reagent due to the favorable formation of $\mathrm{CF}_{3}-\mathrm{CH}=\mathrm{CH}_{2}$ (Scheme 36).

Another way for the preparation of (S)-2-amino-5,5,5-trifluoropentanoic acid (100) was dynamic kinetic resolution (DKR) approach with tri-chlorosubstituted ligand (S)-16 and racemic hydrochloric salt of the 2-amino-5,5,5-trifluoropentanoic acid (100) as the starting materials. The hydrochloric salt of the 2-amino-5,5,5-trifluoropentanoic acid was obtained from the commercially available $\mathrm{N}$-acetyl derivative of $\mathbf{1 0 0}$ by acidic hydrolysis of the $6 \mathrm{~N} \mathrm{HCl}$. In contrast to the alkylation procedure, DKR is usually conducted in an alcohol solvent and the process is not complicated by oxidative reactions leading to the byproducts of type (S)-99. 
<smiles>O=C1CN2C(c3ccccc3)=C3c4ccc(Cl)cc4N4C(=O)[C@@H]5CCCN5[N+]3(Nc3ccc(Cl)c(Cl)c3)OC(=O)N4N2C1</smiles>

(S)-18

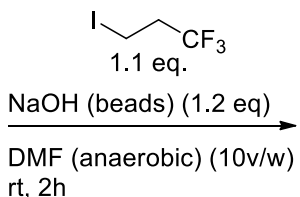

Byproducts:

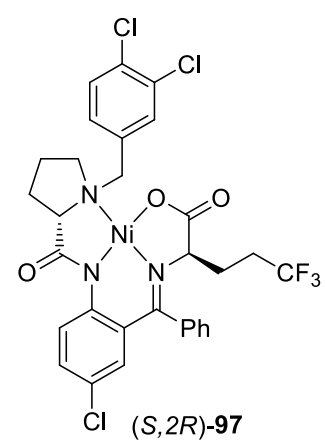

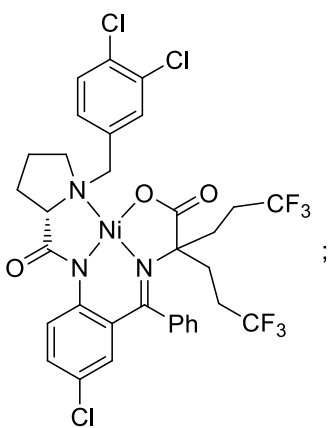

(S)-98

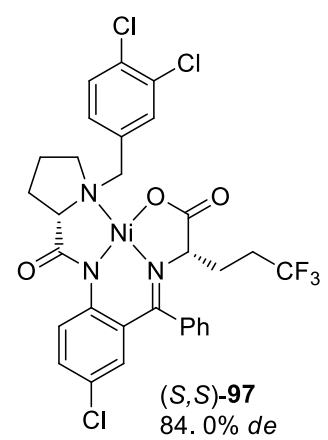

$98.4 \%$ yield of $(S, S)-97(S, 2 R)-97$

Scheme 36. Alkylation of chiral glycine equivalent (S)-18.

The best yield of the product $(S, S)-97(97.0 \%)$ was obtained with the application of 1.4 equiv excess of rac-100, $\mathrm{NiCl}_{2}$, and 7 equiv of the base. Most importantly, product $(S, S)-97$ was obtained in a virtually diastereomerically pure form ( $99.5 \%$ d.e.). Moreover, authors examined the reproducibility of this method for small- as well as larger-scale reactions. For example, using $16.6 \mathrm{~g}$ of ligand (S)-16, they obtained $38.7 \mathrm{~g}$ of $(\mathrm{S}, \mathrm{S})-\mathbf{9 7}$ (97\% yield, $99.5 \%$ d.e.) (Scheme 37$)$.

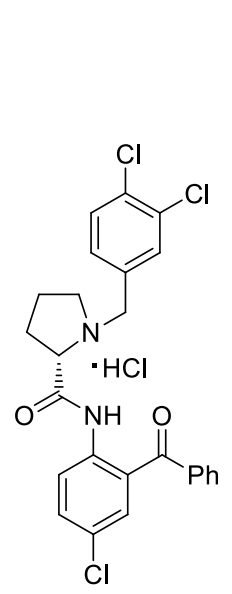

(S)-16

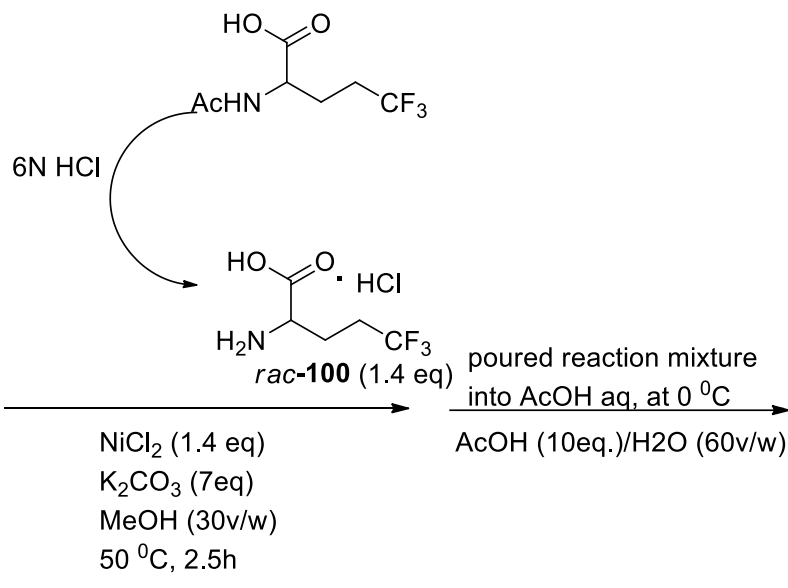

$50^{\circ} \mathrm{C}, 2.5 \mathrm{~h}$<smiles></smiles>

(S,S)-97

$97 \%$

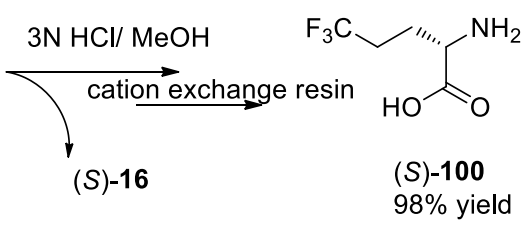

Scheme 37. DKR of 2-amino-5,5,5-trifluoropentanoic acid (100). 
For the demonstration of the conventional preparative value of this method, authors performed a modified disassembly procedure and isolated the Fmoc-derivative of (S)-100 amino acid with excellent chemical yield (93.3\%) and enantiomeric purity $(98.2 \%$ e.e.).

Bremerich et al. reported an interesting way for the general asymmetric synthesis of $\alpha$-amino acids using $N$-(2-benzoylphenyl)-2-(tertbutylamino) propanamide (101) as chiral auxiliary by in situ formation of the corresponding Schiff bases with amino acids followed by complexation with $\mathrm{Ni}(\mathrm{II})$ ions and base-catalyzed thermodynamic equilibrium [114] (Scheme 38). Treatment of $\mathrm{N}$-(2-benzoylphenyl)-2-(tertbutylamino) propanamide (101) with racemic phenylalanine in the presence of $\mathrm{Ni}(\mathrm{II})$ ions afforded separable major product $\left(S_{\mathrm{N}^{*}}\right)\left(S_{C^{*}}\right)\left(S_{\left.C^{*}\right)-\mathbf{1 0 2}}\right.$ and diastereomer $\left(S_{N^{*}}\right)\left(S_{C^{*}}\right)\left(R_{C}^{*}\right)-102$.
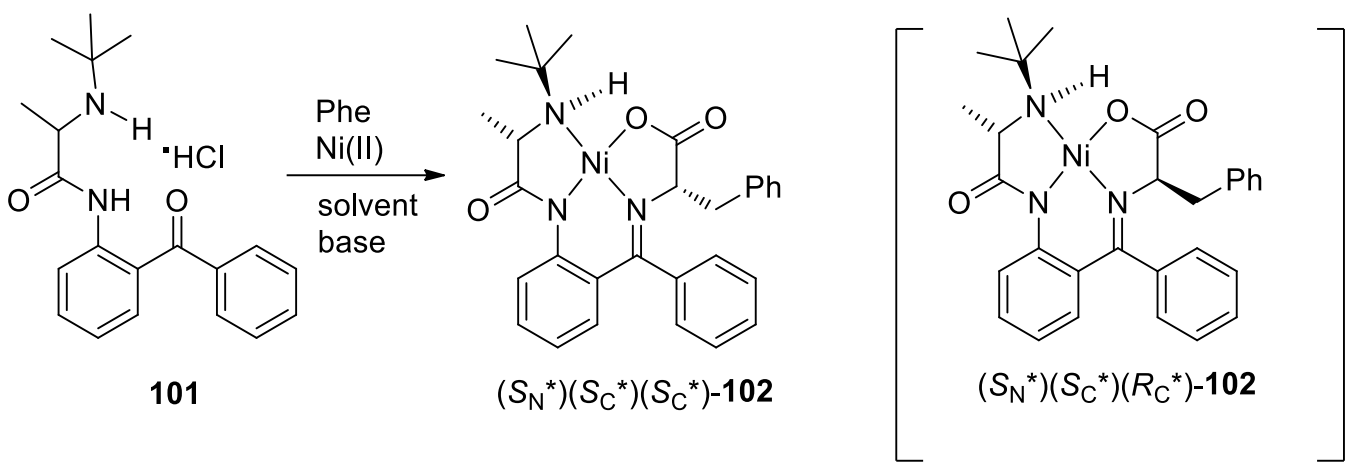

Scheme 38. Reaction of 101 with phenylalanine.

Under the optimal conditions, the reactivity and diastereomeric preferences of $\mathbf{1 0 1}$ complexations with various substituted phenylalanines were investigated. It was shown that the stereochemical outcome of the reactions of mono- and di-substituted phenylalanines was rather similar with $>90 \%$ yields and diastereomeric ratios of about 95:5. Noteworthy, 3,5-di-trifluoromethyl-containing phenylalanine gave virtually complete diastereoselectivity. 3-hydroxy 4-nitro derivatives of phenylalanine were converted very well affording with excellent stereochemical control. To further expand this substrate generality, reactions of $\mathbf{1 0 1}$ with numerous $\alpha$-amino acids bearing various side-chains were performed. Amino acids such as alanine, $\alpha$-aminobutyric acid, norvaline, norleucine and leucine afforded diastereomeric products with both high diastereoselectivities (de $~ 95: 5)$ and excellent chemical yields (88-99\%).

Another way for the resolution of unprotected racemic AAs was developed by Zhou et al. with the use of a new $\alpha$-methylproline-derived ligands [48]. They succeeded to modify the established synthetic procedure for the large-scale preparation of proline ligands (S)- and (R)-106-109 includes the $N$-benzylation of free proline followed by a reaction with an $o$-aminobenzophenone derivative $[59,82]$. They implemented a procedure based on $N$-Boc- $\alpha$-methylproline (103). Using this approach, it was found this reaction quite reliable, reproducible, and operationally convenient for scaling up (Scheme 39).

Ligands 106-109 were then tested in the chemical resolution of $\beta$-phenyl- $\beta$-alanine (Scheme 40). Based on the results, authors concluded that the nature of the substituent on the proline nitrogen atom does not show an obvious effect on the stereochemical outcome. The nickel complexes 111 were isolated in 54-83\% yields and 95:5 to 88:12 diastereoselectivities. The observed subtle differences can be attributed to the steric effects of the substituent on the stabilities of the major and minor products under strongly basic conditions. 


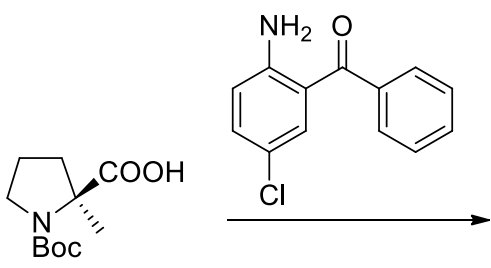

(S) or $(R)-103$

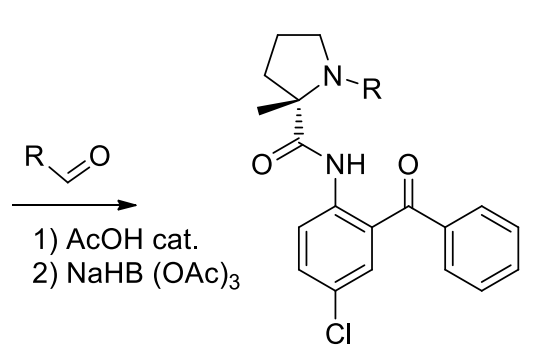

(S) or $(R)-106-109$ $90-95 \%$

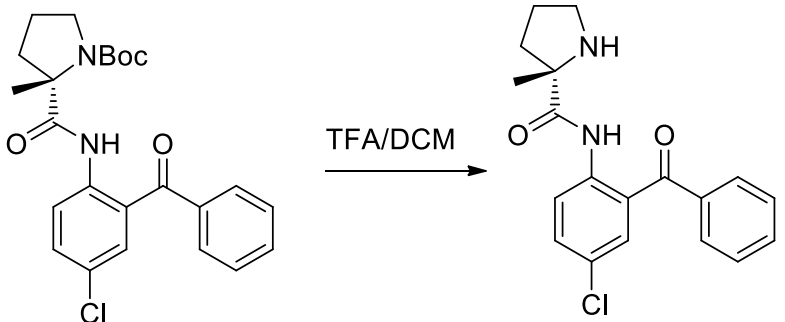

(S) or $(R)-105$ $98 \%$
$(S)$ or $(R)-104$

$62 \%$

$$
\begin{aligned}
& \mathrm{R}=\text { 3.4-dichlorobenzyl (106) } \\
& \mathrm{R}=\text { benzyl (107) } \\
& \mathrm{R}=\text { phenylpropyl (108) } \\
& \mathrm{R}=\text { ehyl (109) }
\end{aligned}
$$

Scheme 39. Synthetic approach to ligands (S)- and (R)-106-109.<smiles>[R]N1CCC[C@]1(C)C(=O)Nc1ccc(Cl)cc1C(=O)c1ccccc1</smiles>

(S) or $(R)-106-109$<smiles>CCCCC(C)(C)OC(=O)OC</smiles>

$\mathrm{CH}_{3} \mathrm{OH}, 80^{\circ} \mathrm{C}$

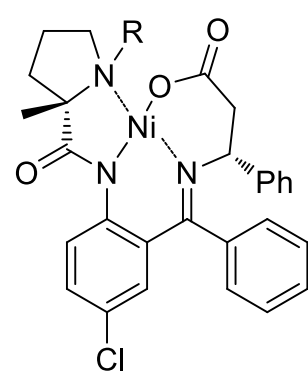

$(S, 2 R)$ - or $(R, 2 S)-111 \mathrm{a}-\mathrm{d}$

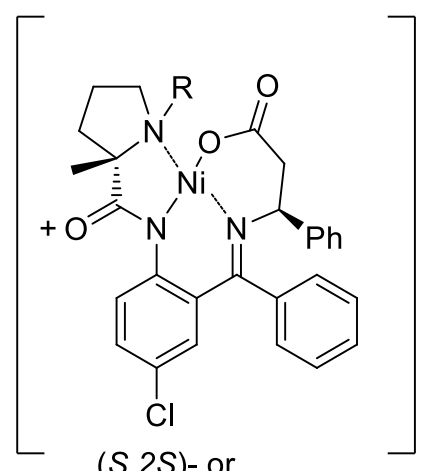

$(S, 2 S)$ - or $(R, 2 R)-111 \mathrm{a}-\mathrm{d}$

Scheme 40. Chemical resolution of $\beta$-phenyl- $\beta$-alanine 110 with new chiral ligands 106-109.

Various substituted $\beta$-amino acids were tested. In the cases of $\beta$-phenyl- $\beta$-substituted racemates, the corresponding diastereomers were obtained with average chemical yields of ca. $90 \%$ and good diastereomeric preferences of more than 90:10. The presence of halogen atoms, alkyl, methoxy or trifluoromethyl group did not show any noticeable influence on the stereochemical outcomes. Racemic $\beta$-amino acids containing heterocyclic moieties, such as pyridyl, thienyl or naphthyl groups, reacted with ligand 109 without any complications to furnish products 111 with excellent yields and diastereomeric ratios (chemical yield $80-95 \%$, d.r. 98:2). In the aliphatic series, racemates bearing straight chains such as methyl, ethyl and $n$-butyl groups reacted well with ligand 109 to afford diastereomers with excellent stereochemical outcomes (chemical yield 76-95\%, d.r. 95:5). Furthermore, authors successfully applied the method to obtain the essential intermediate $\beta$-phenyl- $\beta$-alanine $(92 \%$ chemical yield, and $>99 \%$ e.e.) in the synthesis of the anti-HIV drug maraviroc in an overall yield of $49 \%$, which possibly makes it of great interest to industry.

\section{Miscellaneous Reactions}

Due to the special role of $\alpha$-substituted mercaptoglycine derivatives in many bioactive compounds $[115,116]$, the development of efficient methodologies for the synthesis of $\alpha$-substituted mercaptoglycine derivatives has attracted great attention. In 2017, Wang and co-authors developed 
a synthetic method for the preparation of the chiral $\alpha$-substituted mercaptoglycine derivatives $(S)(2 S)-113$ via an asymmetric substitution reaction of $\mathrm{Ni}(\mathrm{II})$ complex (S)-2 with $S$-substituted 4-methylbenzenesulfonothioates as the sulfur sources (Scheme 41) [117]. After careful optimization of reaction conditions, they found that the reaction could proceed very well with 2.0 equiv of DBU as a base in $t-\mathrm{BuOH}$ at room temperature. The reaction showed good functional group tolerance, and total fifteen examples of $S$-substituted 4-methyl-benzenesulfonothioates were examined with good chemical yields (7-98\%) and excellent diastereoselectivities (92:8-95:5 d.r.). However, the substrate bearing a 4-trifluoromethylbenzyl strong electron-withdrawing group, was found to be unsuitable for this reaction and less than $10 \%$ yield was found. It should be mentioned that the substrates featuring cycloalkyl and ethyl groups were also well tolerated in this reaction.

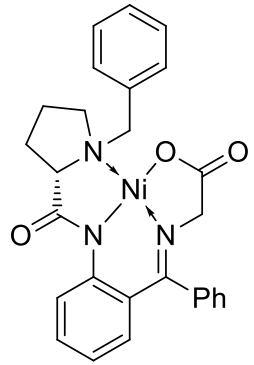

(S)-2

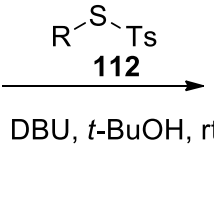

O<smiles>CSCC1=NCCCC1c1ccccc1</smiles>

$(S)(2 S)-113$

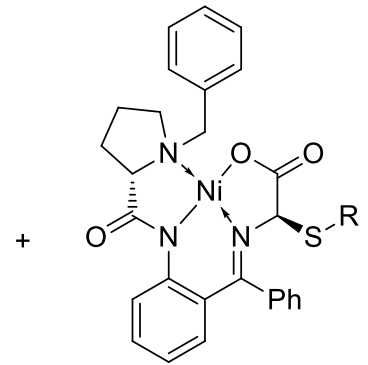

$(S)(2 R)-113$

15 examples

7-98\% yields, 92:8-95:5 dr

naphthyl, $71 \%$ yield, $92: 8 \mathrm{dr}$ cyclohexylmethyl, $94 \%$ yield, $93: 7 \mathrm{dr}$ cyclopentyl, 55\% yield, 95:5 dr ethyl, $63 \%$ yield, $92: 8 \mathrm{dr}$

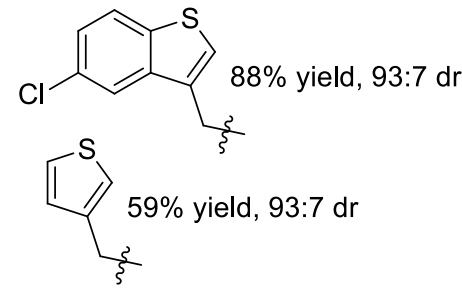

Scheme 41. Asymmetric synthesis of chiral $\alpha$-benzyl mercaptoglycine derivatives.

In 2017, Magdesieva and co-workers developed a one-pot method for the asymmetric synthesis of $\alpha$-thioalkylated amino acids under electrochemical reaction conditions (Scheme 42) [118].

This thioakylation reaction of $\mathrm{Ni}$ complex (S)-2 was conducted in a divided $H$-type cell in the presence of azobenzene at a constant potential $(-1.40 \mathrm{~V}$ vs. $\mathrm{Ag} / \mathrm{AgCl} / \mathrm{KCl})$, which proceeded smoothly to give the corresponding thioalkylated amino acid derivatives in up to $72 \%$ yield and 11:1 diastereoselectivity. Two alkyl thiocyanates, benzyl and ethyl thiocyanate were employed in this reaction, and the same level of yield and diastereoselectivity were found. The absolute configuration of the newly generated carbon center is $(S)$, which has been confirmed by the x-ray single crystal analysis of complex 114b.

According to the results from cyclic voltammetry (CV) experiments, one possible mechanism was proposed, which proceeds via the sequence of reduction of azobenzene at cathode to give the radical anion, deprotonation of Ni complex and substitution of thiocyanate. It was worth mentioning that thiocyanates acted very well as the thioakylation reagents in this electrochemical reaction, and could avoid the epimerization of the product when common bases were used. 


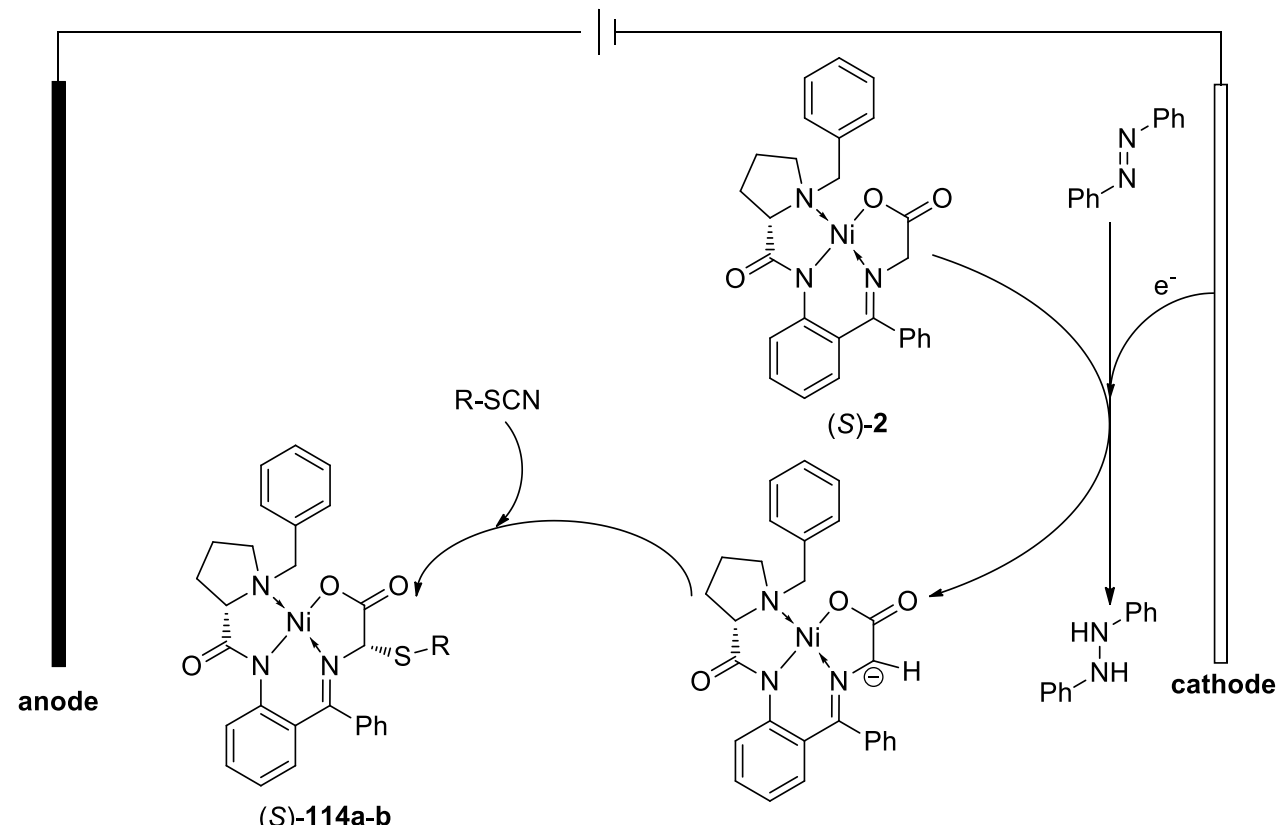

$(S, S)-114 a: R=\mathrm{CH}_{2} \mathrm{Ph} \quad 67 \%$ yield, $(S) /(R)=11: 1$

$(S, S)-114 b: \mathrm{R}=\mathrm{CH}_{2} \mathrm{CH}_{3} 72 \%$ yield, $(S) /(R)=10: 1$

Scheme 42. Electrochemical reaction of Ni complex and thiocyanates.

In 2018, Belokon and co-workers [119] reported the simple approach for the synthesis of amino acids bearing a 1,2,3-triazole functionality via a copper(I) iodide catalyzed click reaction between alkynyl $\mathrm{Ni}(\mathrm{II})$ complex (S)-115 and alkyl azide (Scheme 43). It should be mentioned that the $\mathrm{Ni}$ (II) complex (S)-115 could be obtained easily via the alkylation reaction of propargyl bromide with Gly-based $\mathrm{Ni}$ complex (S)-2 in the presence of base. The cycloaddition proceeded smoothly with triethylamine as a base in DMSO at $70{ }^{\circ} \mathrm{C}$ for $7 \mathrm{~h}$, affording the chiral triazole products 115 in 39-92\% yields. The reaction showed good functional group tolerance. Notably, diazide also could react with complex (S)-116, resulting in the bis-triazole $\mathrm{Ni}(\mathrm{II})$ complex in $39 \%$ yield.<smiles>O=C1CN2C(c3ccccc3)=C3C=CC=CC3N3C(=O)[C@@H]4CCCN4[N+]23OC1=[18O]</smiles>

(S)-2<smiles>C#CC[C@H]1C(=O)O[N+]23OC4(Cc5ccccc5)N5CCC[C@H]5C(=O)N(c5ccccc5C(c5ccccc5)N12)[N+]43</smiles>

$(S)-115$

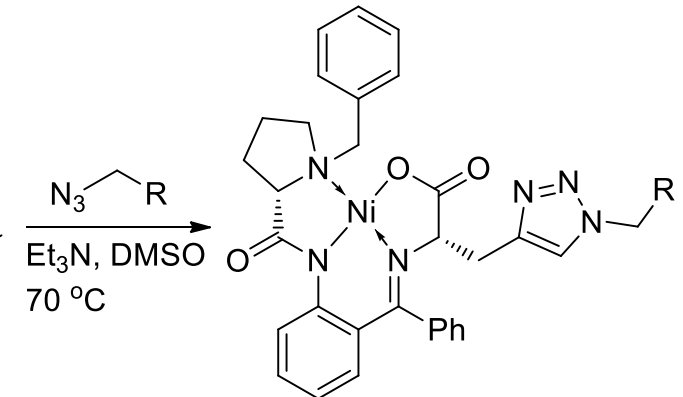

(S)-116

$$
\begin{aligned}
& \mathrm{R}=\mathrm{Ph}, 71 \% \text { yield } \\
& \text { 4- } \mathrm{CNC}_{6} \mathrm{H}_{4}, 40 \% \text { yield } \\
& 2-\mathrm{FC}_{6} \mathrm{H}_{4}, 92 \% \text { yield 1-naphthyl, } 91 \% \text { yield } \\
& \text { 4-i } \mathrm{PrC}_{6} \mathrm{H}_{4}, 75 \% \text { yield } \mathrm{N}_{3} \mathrm{CH}_{2} \mathrm{C}_{6} \mathrm{H}_{4}, 39 \% \text { yield }
\end{aligned}
$$

11 examples, $39 \%-92 \%$ yield

Scheme 43. Synthesis of triazoles via click reaction of Ni complex (S)-115.

The disassembly of (S)-116 to free amino acid (S)-117 was developed in this work. The desired triazole containing amino acids (S)-117 could be isolated in excellent yields and high enantioselectivities (>99\% ee) under the acidic conditions (Scheme 44 ). The chiral ligand was easily separated and could be used for the next synthesis cycle. 
<smiles></smiles>

(S)-116

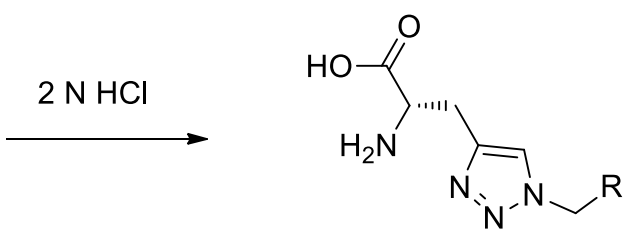

(S)-117

Scheme 44. Disassembly of the Ni complex (S)-116 to give free amino acid (S)-117.

The authors extended this click reaction to another Gly-based Ni complex (S)-119 under the same reaction conditions. The $\mathrm{Ni}(\mathrm{II})$ complex (S)-119 was prepared via a two-step synthetic method. The Ni(II) complex (S)-118 was prepared by the Michael addition of malonic ester to dehydroalanine (S)-78 [120]. Then, the alkylation of (S)-118 with propargyl bromide in the presence of base afforded the Ni(II) complex (S)-119 in 95\% yield and d.r. > 99:1 (Scheme 45). The click reaction of (S)-119 with eleven examples of azides was successfully achieved in the presence of triethylamine with $\mathrm{CuI}$ as a catalyst at $70{ }^{\circ} \mathrm{C}$, affording the chiral triazole products in $38-93 \%$ yields. For most cases of the azides, good yields were observed. However, for a strong electron withdrawing-group on the azide-bearing phenyl, such as 4-cyano, a poor yield was found (40\%).

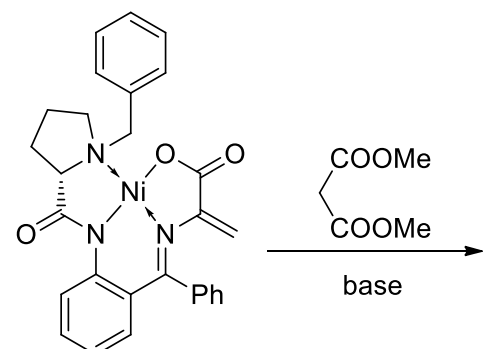

(S)-78

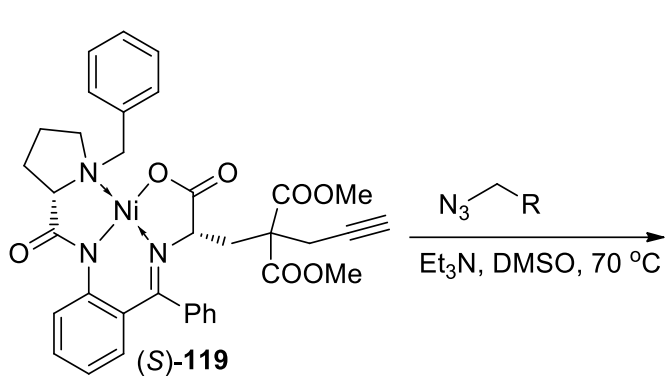

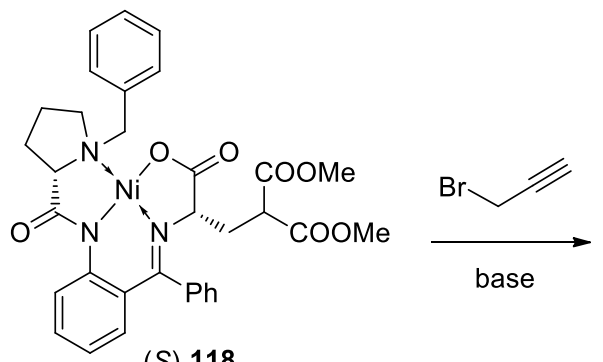

$(S)-118$

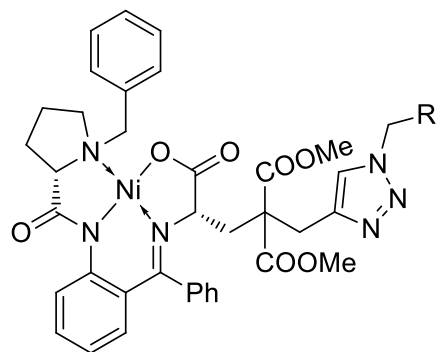

(S)-120

11 examples, $38-93 \%$ yield

$$
\begin{array}{cl}
\mathrm{R}=\mathrm{Ph}, 90 \% \text { yield, } & 4-\mathrm{CNC}_{6} \mathrm{H}_{4}, 38 \% \text { yield } \\
2-\mathrm{FC}_{6} \mathrm{H}_{4}, 73 \% \text { yield, } & 1-\text { naphthyl, } 75 \% \text { yield } \\
2-\mathrm{ClC}_{6} \mathrm{H}_{4}, 93 \% \text { yield, } & \mathrm{N}_{3} \mathrm{CH}_{2} \mathrm{C}_{6} \mathrm{H}_{4}, 68 \% \text { yield }
\end{array}
$$

Scheme 45. Synthesis of Ni(II) complex (S)-119 and its click reaction.

In 2017, Soloshonok, Liu [121] and co-workers reported their studies on the effect of substituents on glycine-based Ni complexes on stereochemical preferences. A series of glycine-based Ni complexes $(\mathbf{1 2 1} \mathbf{a}-\mathbf{h})$ containing different substitutions on the proline $N$-benzyl group or $o$-amino-benzophenone moiety were synthesized. Also, the methylation of complexes $121 a-h$ with the use of MeI in the presence of base was conducted and the corresponding Ni complexes (122a-h) were obtained (Scheme 46). They assumed that the substitutions on the proline $\mathrm{N}$-benzyl and o-amino-benzophenone moieties are 
far away from the carbon center of glycine moiety and most probably have no obvious electronic and steric effects on the stereochemical outcome of the related asymmetric reactions. However, the existence of these substitutions may lead to changes of the intramolecular interactions and Ni(II) chelating models. Consequently, thirteen single crystals of $\mathrm{Ni}$ (II) complexes were prepared and subjected to the x-ray crystallographic analysis. The analysis of crystal structures clearly shows that almost no aromatic-aromatic interactions were detected for complex 121a, while obvious interactions were found for the substituted complex 121b. Analysis of complexes $(S)(2 S)-\mathbf{1 2 2} \mathbf{a}$ and $\mathbf{1 2 2} \mathbf{b}$ found that the distance between the aryl C-H hydrogen atom and the $o$-carbon of the benzophenone ring in $\mathbf{1 2 2} \mathbf{b}$ is greater than in unsubstituted complex 122a, which indicates $\mathbf{1 2 2 b}$ is more thermodynamically stable. The same phenomena are found in those substituted complexes $\mathbf{1 2 2} \mathbf{b}-\mathbf{d}$. These findings could be used for the design of new Ni complex for the asymmetric synthesis of amino acids.

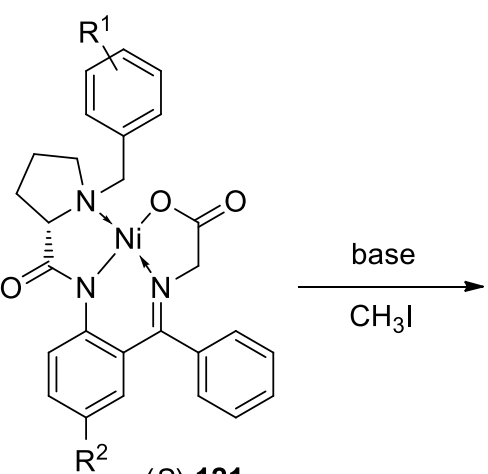

(S)-121

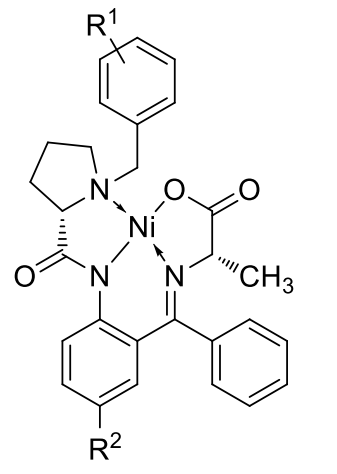

$(S)(S)-122$

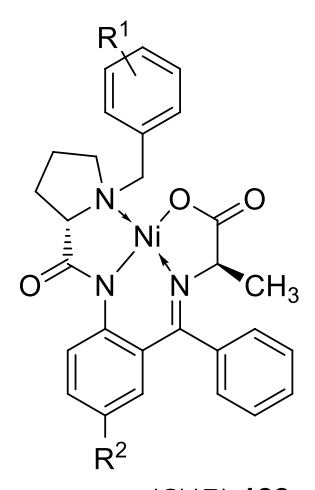

$(S)(R)-122$

$$
\begin{aligned}
& \text { 122e: } R^{1}=3,4-\mathrm{Cl}_{2}, R^{2}=H \\
& \text { 122f }: R^{1}=3,4-\mathrm{Me}_{2}, R^{2}=H \\
& \text { 122g: } R^{1}=2-F, R^{2}=H \\
& \text { 122h: } R^{1}=3-F, R^{2}=H
\end{aligned}
$$

Scheme 46. Structure of Ni complex 121a-h and their methylation derivatives.

Han [122], Soloshonok, and co-workers designed a new glycine-based Ni(II) complex, which contains only one single-nitrogen stereogenic center. This new Ni complex was synthesized starting from $N$-(2-benzoylphenyl)-2-bromoacetamide and isopropylamine (Scheme 47). The obtained amine intermediate 123 was converted into the designed Ni complex 124 via a reaction with nickel nitrate hexahydrate and glycine in the presence of $\mathrm{K}_{2} \mathrm{CO}_{3}$. The new Ni complex was used for measuring the $\mathrm{Ni}$ (II) complex configurational stability via high-performance liquid chromatography (HPLC)-assisted evaluation. The results showed that the stability mainly depends on the solvent, which ranges from $t_{\frac{1}{2}}$ less than 5 min to completely stable $\left(\mathrm{t}_{\frac{1}{2}} 90\right.$ year) at room temperature.

Shortly after that work, the same authors extended their work to other metal(II) complexes of $\alpha$-amino acid Schiff bases to investigate the general rule on the effect of substituents on the configurational stability of the stereogenic nitrogen in such type of metal(II) complexes (Scheme 48) [123]. They synthesized ten complexes with variations of amino group, substitution on $o$-amino-benzophenone and transition-metal by using of the similar method reported previously. Generally, $\mathrm{Cu}$ (II) complex is obviously less stable as compared with $\mathrm{Ni}(\mathrm{II})$ and $\mathrm{Pd}(\mathrm{II})$; the N-methylamine-based complex (127) is more stable than those with $\mathrm{N}-\mathrm{H}$ type complexes $(\mathbf{1 2 5 , 1 2 6 )}$. 
<smiles>CC(C)NNCC(=O)Nc1ccccc1C(=O)c1ccccc1</smiles><smiles></smiles>

$(R)-124$<smiles></smiles>

(S)-124

Scheme 47. Synthesis of ligand 123 and racemic glycine Schiff base Ni(II) complex 124.<smiles></smiles>

125<smiles></smiles>

128<smiles>O=C1CN2C(c3ccccc3)=N[N+]3(NCc4ccccc4)N(C1)CC(=O)N23</smiles>

126<smiles></smiles>

127<smiles></smiles><smiles></smiles><smiles></smiles><smiles></smiles><smiles></smiles><smiles></smiles>

Scheme 48. Structures of complex 125-134.

\section{Conclusions}

The results discussed in this review article clearly underscore the leading position of $\mathrm{Ni}(\mathrm{II})$ complexes as the methodology of choice for asymmetric syntheses of tailor-made AA. The variety of chiral tridentate ligands and reaction chemistry continue to grow. While our aim was to present as comprehensive treatment of the subject as possible, we eventually missed some of the relevant data that were kindly pointed to us during the profound and very thoughtful refereeing 
of this work. These include Michael additions of chiral glycine Schiff base Ni(II)-complex with 1-(1-phenylsulfonyl)benzene [124], synthesis of $\beta$-substituted-tryptophans via three-component reactions of glycine $\mathrm{Ni}(\mathrm{II})$-complex [125], synthesis of $\beta$-substituted $\alpha, \gamma$-diaminobutyric acid derivatives via Michal addition reactions [126] and an approach to $\gamma$-amino acids via Ni-catalyzed carbodifunctionalization of $N$-vinylamides [127]. Besides, novel application of amino acids in functional supramolecular materials $[128,129]$ might also be of interest. The readers should consult these references for a more comprehensive overview of the developments in the field. Several notable trends can be pointed out as they, most likely, will define future research in this area. First of all, the readers can see the application of $\mathrm{Ni}(\mathrm{II})$ complexes as protective platform for the modification of side chain of the already assembles AAs. This trend is exemplified by the Suzuki coupling reactions and click chemistry. Compared to conventional types of protection, the assembly/disassembly of the corresponding $\mathrm{Ni}$ (II) complexes present a more simple and general solution. One may expect this line of application of $\mathrm{Ni}$ (II) complexes will be used by many research groups. Another interesting trend is a growing interest in electrochemical reactions. This is, probably, a reflection of "green" chemistry mentality deservingly taking roots in chemical practice. Also, we would like to mention the interest in more fundamental aspects of $\mathrm{Ni}$ (II) complexes structure and stereogenic properties, in particular related to the stereogenic nitrogen, its configurational stability and overall effect on the stereochemical outcome of the homologation reactions. Finally, most important in our opinion trend, is application of $\mathrm{Ni}$ (II) complexes methodology on large, near industrial scale. Some reactions have been conducted on multi-kilogram scale underscoring true practicality of this approach. One may confidently conclude, the discussed in this article developments over the last four years, bode well for future growth and methodological dominance of $\mathrm{Ni}(\mathrm{II})$ complex chemistry for practical preparation of structurally diverse tailor-made AAs for exciting applications in medicinal chemistry and drug design.

Author Contributions: Conceptualization, J.H.; K.I. and V.A.S.; validation, V.A.S.; H.K.; H.M. and A.S.S.; writing-original draft preparation, Y.Z., H.K. and A.F.M.; writing-review and editing, V.A.S.; K.I. and J.H.; supervision, V.A.S. All authors have read and agreed to the published version of the manuscript.

Funding: This research was funded by the National Natural Science Foundation of China (No. 21761132021), and IKERBASQUE, Basque Foundation for Science.

Acknowledgments: We thank the support from Qin Lan Project of Jiangsu Province China.

Conflicts of Interest: The authors declare no conflict of interest.

\section{References}

1. Soloshonok, V.A.; Cai, C.; Hruby, V.J.; Meervelt, L.V. Asymmetric Synthesis of Novel Highly Sterically Constrained (2S,3S)-3-Methyl-3-Trifluoromethyl- and (2S,3S,4R)-3-Trifluoromethyl-4-Methylpyroglutamic Acids. Tetrahedron 1999, 55, 12045-12058. [CrossRef]

2. Soloshonok, V.A.; Izawa, K. Asymmetric Synthesis and Application of $\alpha$-Amino Acids, ACS Symposium Series \#1009; Soloshonok, V.A., Izawa, K., Eds.; Oxford University Press: Washington, DC, USA, 2009.

3. Blaskovich, M.A.T. Unusual amino acids in medicinal chemistry. J. Med. Chem. 2016, 59, 10807-10836. [CrossRef] [PubMed]

4. Mei, H.; Han, J.; White, S.; Graham, D.J.; Izawa, K.; Sato, T.; Fustero, S.; Meanwell, N.A.; Soloshonok, V.A. Tailor-Made Amino Acids and Fluorinated Motifs as Prominent Traits in the Modern Pharmaceuticals. Chem. Eur. J. 2020. [CrossRef]

5. Mei, H.; Han, J.; Klika, K.D.; Izawa, K.; Sato, T.; Meanwell, N.A.; Soloshonok, V.A. Applications of Fluorine-Containing Amino Acids for Drug Design. Eur. J. Med. Chem. 2020, 186, 111826. [CrossRef]

6. Ma, J.S. Unnatural amino acids in drug discovery. Chim. Oggi-Chem. Today 2003, 21, 65-68.

7. Sato, T.; Izawa, K.; Aceña, J.L.; Liu, H.; Soloshonok, V.A. Tailor-Made $\alpha$-Amino Acids in the Pharmaceutical Industry: Synthetic Approaches to $(1 R, 2 S)$-1-Amino-2-vinylcyclopropane-1-carboxylic Acid (Vinyl-ACCA). Eur. J. Org. Chem. 2016, 2016, 2757-2774. [CrossRef]

8. Hodgson, D.R.W.; Sanderson, J.M. The synthesis of peptides and proteins containing non-natural amino acids. Chem. Soc. Rev. 2004, 33, 422-430. [CrossRef] 
9. Henninot, A.; Collins, J.C.; Nuss, J.M. The current state of peptide drug discovery: Back to the future? J. Med. Chem. 2018, 61, 1382-1414. [CrossRef]

10. Fosgerau, K.; Hoffmann, T. Peptide therapeutics: Current status and future directions. Drug Discov. Today 2015, 20, 122-128. [CrossRef]

11. Craik, D.J.; Fairlie, D.P.; Liras, S.; Price, D. The future of peptide-based drugs. Chem. Biol. Drug Des. 2013, 81, 136-147. [CrossRef]

12. Stevenazzi, A.; Marchini, M.; Sandrone, G.; Vergani, B.; Lattanzio, M. Amino acidic scaffolds bearing unnatural side chains: An old idea generates new and versatile tools for the life sciences. Bioorg. Med. Chem. Lett. 2014, 24, 5349-5356. [CrossRef] [PubMed]

13. Kim, Y.; Park, J.; Kim, M.J. Dynamic kinetic resolution of amines and amino acids by enzyme-metal cocatalysis. Chem. Cat. Chem. 2011, 3, 271-277. [CrossRef]

14. So, S.M.; Kim, H.; Mui, L.; Chin, J. Mimicking nature to make unnatural amino acids and chiral diamines. Eur. J. Org. Chem. 2012, 2012, 229-241. [CrossRef]

15. D'Arrigo, P.; Cerioli, L.; Servi, S.; Viani, F.; Tessaroa, D. Synergy between catalysts: Enzymes and bases. DKR of non-natural amino acids derivatives. Cat. Sci. Technol. 2012, 2, 1606-1616. [CrossRef]

16. Soloshonok, V.A.; Sorochinsky, A.E. Practical methods for the synthesis of symmetrically $\alpha, \alpha$-Disubstituted- $\alpha$-amino acids. Synthesis 2010, 2319-2344. [CrossRef]

17. D'Arrigo, P.; Cerioli, L.; Fiorati, A.; Servi, S.; Viani, F.; Tessaroa, D. Naphthyl-1- $\alpha$-amino acids via chemo-enzymatic dynamic kinetic resolution. Tetrahedron Asymmetry 2012, 23, 938-944. [CrossRef]

18. Periasamy, M.; Gurubrahamam, R.; Sanjeevakumar, N.; Dalai, M.; Alakonda, L.; Reddy, P.O.; Suresh, S.; Satishkumar, S.; Padmaja, M.; Reddy, M.N.; et al. Convenient methods for the synthesis of chiral amino alcohols and amines. Chimia 2013, 67, 23-29. [CrossRef]

19. Bera, K.; Namboothiri, I. Asymmetric synthesis of quaternary $\alpha$-amino acids and their phosphonate analogues. Asian J. Org. Chem. 2014, 3, 1234-1260. [CrossRef]

20. Metz, A.E.; Kozlowski, M.C. Recent advances in asymmetric catalytic methods for the formation of acyclic $\alpha, \alpha$-disubstituted $\alpha$-amino acids. J. Org. Chem. 2015, 80, 1-7. [CrossRef]

21. He, G.; Wang, B.; Nack, W.A.; Chen, G. Syntheses and transformations of $\alpha$-amino acids via palladium-catalyzed auxiliary-directed sp3 C-H functionalization. Acc. Chem. Res. 2016, 49, 635-645. [CrossRef]

22. Han, J.; Sorochinsky, A.E.; Ono, T.; Soloshonok, V.A. Biomimetic Transamination-a Metal-Free Alternative to the Reductive Amination. Application for Generalized Preparation of Fluorine-Containing Amines and Amino Acids. Curr. Org. Synth. 2011, 8, 281-294. [CrossRef]

23. Romoff, T.T.; Ignacio, B.G.; Mansour, N.; Palmer, A.B.; Creighton, C.J.; Abe, H.; Moriwaki, H.; Han, J.; Konno, H.; Soloshonok, V.A. Large-Scale Synthesis of the Glycine Schiff Base Ni(II) Complex Derived from $(S)$ - and (R)-N-(2-Benzoyl-4-chlorophenyl)-1-[(3,4-dichlorophenyl)methyl]-2-pyrrolidinecarboxamide. Org. Process. Res. Dev. 2020, 24, 294-300. [CrossRef]

24. Han, J.; Romoff, T.T.; Moriwaki, H.; Konno, H.; Soloshonok, V.A. Development of Hamari Ligands for Practical Asymmetric Synthesis of Tailor-Made Amino Acids. ACS Omega 2019, 4, 18942-18947. [CrossRef] [PubMed]

25. Belokon, Y.N.; Zel'tzer, I.E.; Bakhmutov, V.I.; Saporovskaya, M.B.; Ryzhov, M.G.; Yanovsky, A.I.; Struchkov, Y.T.; Belikov, V.M. Asymmetric synthesis of threonine and partial resolution and retroracemization of alpha.-amino acids via copper(II) complexes of their Schiff bases with (S)-2-N-( $N^{\prime}$-benzylprolyl)aminobenzaldehyde and (S)-2- $N-\left(N^{\prime}\right.$-benzylprolyl)aminoacetophenone. Crystal and molecular structure of a copper(II) complex of glycine Schiff base with (S)-2-N-(N'-benzylprolyl)aminoacetophenone. J. Am. Chem. Soc. 1983, 105, 2010-2017.

26. Belokon, Y.N.; Bulychev, A.G.; Vitt, S.V.; Struchkov, Y.T.; Batsanov, A.S.; Timofeeva, T.V.; Tsyryapkin, V.A.; Ryzhov, M.G.; Lysova, L.A.; Bakhmutov, V.I.; et al. General method of diastereo- and enantioselective synthesis of $\beta$-hydroxy- $\alpha$-amino acids by condensation of aldehydes and ketones with glycine. J. Am. Chem. Soc. 1985, 107, 4252-4259. [CrossRef]

27. Belokon, Y.N.; Chernoglazova, N.I.; Kochetkov, C.A.; Garbalinskaya, N.S.; Belikov, V.M. Preparation of optically pure $\alpha$-methyl- $\alpha$-amino acids via alkylation of the nickel(II) Schiff base of $(R, S)$-alanine with (S)-2-N-(N'-benzylprolyl)aminobenzaldehyde. J. Chem. Soc. Chem. Commun. 1985, 171-172. [CrossRef] 
28. Jörres, M.; Chen, X.; Aceña, J.L.; Merkens, C.; Bolm, C.; Liu, H.; Soloshonok, V.A. Asymmetric Synthesis of a-Amino Acids under Operationally Convenient Conditions. Adv. Synth. Catal. 2014, 356, 2203-2208. [CrossRef]

29. Takeda, R.; Kawamura, A.; Kawashima, A.; Sato, T.; Moriwaki, H.; Izawa, K.; Abe, H.; Soloshonok, V.A. Second-order asymmetric transformation and its application for the practical synthesis of $\alpha$-amino acids. Org. Biomol. Chem. 2018, 16, 4968-4972. [CrossRef]

30. Soloshonok, V.A.; Ellis, T.K.; Ueki, H.; Ono, T. Resolution/Deracemization of Chiral $\alpha$-Amino Acids Using Resolving Reagents with Flexible Stereogenic Centers. J. Am. Chem. Soc. 2009, 131, 7208-7209. [CrossRef]

31. Takeda, R.; Kawamura, A.; Kawashima, A.; Sato, T.; Moriwaki, H.; Izawa, K.; Akaji, K.; Wang, S.; Liu, H.; Aceña, J.L.; et al. Chemical Dynamic Kinetic Resolution and $(S) /(R)$-Interconversion of Unprotected $\alpha$-Amino Acids. Angew. Chem. Int. Ed. 2014, 53, 12214-12217. [CrossRef]

32. Zhou, S.; Wang, J.; Chen, X.; Aceña, J.L.; Soloshonok, V.A.; Liu, H. Recyclable Ligands for the Non-Enzymatic Dynamic Kinetic Resolution of Challenging $\alpha$-Amino Acids. Angew. Chem. Int. Ed. 2015, 54, 12918-12922.

33. Sorochinsky, A.E.; Ueki, H.; Aceña, J.L.; Ellis, T.K.; Moriwaki, H.; Soloshonok, V.A. Chemical approach for interconversion of (S)- and (R)- $\alpha$-amino acids. Org. Biomol. Chem. 2013, 11, 4503-4507. [CrossRef] [PubMed]

34. Zhou, S.; Wang, J.; Chen, X.; Aceña, J.L.; Soloshonok, V.A.; Liu, H. Chemical Kinetic Resolution of Unprotected b-Substituted-b-Amino Acids Using Recyclable Chiral Ligands. Angew. Chem. Int. Ed. 2014, 53, 7883-7886. [CrossRef] [PubMed]

35. Wang, J.; Lin, D.; Zhou, S.; Soloshonok, V.A.; Liu, H. Asymmetric Synthesis of Sterically Constrained Linear Trifluoromethyl Containing Amino Acids via Alkylation of Chiral Equivalents of Nucleophilic Glycine and Alanine. J. Org. Chem. 2011, 76, 684-687. [CrossRef]

36. Tang, X.; Soloshonok, V.A.; Hruby, V.J. Convenient Asymmetric Synthesis of Enantiomerically Pure 2',6'-Dimethyltyrosine (DMT) via Alkylation of Chiral Nucleophilic Glycine Equivalent. Tetrahedron: Asymmetry 2000, 11, 2917-2925. [CrossRef]

37. Ellis, T.K.; Martin, C.H.; Tsai, G.M.; Ueki, H.; Soloshonok, V.A. Efficient Synthesis of Sterically Constrained Symmetrically $\alpha, \alpha$-Disubstituted $\alpha$-Amino Acids under Operationally Convenient Conditions. J. Org. Chem. 2003, 68, 6208-6214. [CrossRef]

38. Ellis, T.K.; Hochla, V.M.; Soloshonok, V.A. Efficient Synthesis of 2-Aminoindane-2-Carboxylic Acid via Dialkylation of Nucleophilic Glycine Equivalent. J. Org. Chem. 2003, 68, 4973-4976. [CrossRef]

39. Soloshonok, V.A.; Tang, X.; Hruby, V.J.; Meervelt, L.V. Asymmetric Synthesis of $\alpha, \beta$-Dialkyl- $\alpha$-Phenylalanines via Direct Alkylation of Chiral Alanine Derivative with Racemic $\alpha$-Alkylbenzylbromides. A Case of High Enantiomer Differentiation at Room Temperature. Org. Lett. 2001, 3, 341-343. [CrossRef]

40. Taylor, S.M.; Yamada, T.; Ueki, H.; Soloshonok, V.A. Asymmetric Synthesis of Enantiomerically Pure 4-Aminoglutamic Acids via Methylenedimerization of Chiral Glycine Equivalents with Dichloromethane under Operationally Convenient Conditions. Tetrahedron Lett. 2004, 45, 9159-9162. [CrossRef]

41. Ellis, T.K.; Martin, C.H.; Ueki, H.; Soloshonok, V.A. Efficient, Practical Synthesis of Symmetrically $\alpha, \alpha$-Disubstituted $\alpha$-Amino Acids. Tetrahedron Lett. 2003, 44, 1063-1066. [CrossRef]

42. Soloshonok, V.A.; Kukhar, V.P.; Galushko, S.V.; Svistunova, N.Y.; Avilov, D.V.; Kuzmina, N.A.; Raevski, N.I.; Struchkov, Y.T.; Pisarevsky, A.P.; Belokon, Y.N. General Method for the Synthesis of Enantiomerically Pure $\beta$-Hydroxy- $\alpha$-Amino Acids, Containing Fluorine Atoms in the Side Chains. Case of Stereochemical Distinction Between Methyl and Trifluoromethyl Groups. X-Ray Crystal and Molecular Structure of the Nickel(II) Complex of (2S,3S)-2-(Trifluoromethyl)threonine. J. Chem. Soc. Perkin Trans. 1 1993, 3143-3155.

43. Soloshonok, V.A.; Avilov, D.V.; Kukhar, V.P. Asymmetric Aldol Reactions of Trifluoromethyl Ketones with a Chiral Ni(II) Complex of Glycine: Stereocontrolling Effect of the Trifluoromethyl Group. Tetrahedron 1996, 52, 12433-12442. [CrossRef]

44. Soloshonok, V.A.; Avilov, D.V.; Kukhar, V.P.; Meervelt, L.V.; Mischenko, N. Highly Diastereoselective aza-Aldol Reactions of a Chiral Ni(II) Complex of Glycine with Imines. An Efficient Asymmetric Approach to 3-Perfluoroalkyl-2,3-Diamino Acids. Tetrahedron Lett. 1997, 38, 4671-4674. [CrossRef]

45. Kawamura, A.; Moriwaki, H.; Röschenthaler, G.-V.; Kawada, K.; Aceña, J.L.; Soloshonok, V.A. Synthesis of $(2 S, 3 S)$ - $\beta$-(trifluoromethyl)- $\alpha, \beta$-diamino acid by Mannich addition of glycine Schiff base Ni(II) complexes to N-tert-butylsulfinyl-3,3,3-trifluoroacetaldimine. J. Fluorine Chem. 2015, 171, 67-72. [CrossRef]

46. Soloshonok, V.A.; Avilov, D.V.; Kukhar, V.P.; Meervelt, L.V.; Mischenko, N. An Efficient Asymmetric Synthesis of (2S,3S)-3-Trifluoromethylpyroglutamic Acid. Tetrahedron Lett. 1997, 38, 4903-4904. [CrossRef] 
47. Soloshonok, V.A.; Cai, C.; Hruby, V.J. Asymmetric Michael Addition Reactions of Chiral Ni(II) Complex of Glycine with N-(Enoyl)oxazolidinones: Improved Reactivity and Stereochemical Outcome. Tetrahedron: Asymmetry 1999, 10, 4265-4269. [CrossRef]

48. Zhou, S.; Wang, S.; Wang, J.; Nian, Y.; Peng, P.; Soloshonok, V.A.; Liu, H. Configurationally Stable (S)- and $(R)-\alpha$-Methylproline-Derived Ligands for the Direct Chemical Resolution of Free Unprotected $\beta^{3}$-Amino Acids. Eur. J. Org. Chem. 2018, 1821-1832. [CrossRef]

49. Konno, H.; Han, J.L.; Moriwaki, H.; Oyama, K.; Soloshonok, V.A. Synthesis of Ahod moiety of ralstonin A using amino acid Schiff base Ni(II)-complex chemistry. Helv. Chim. Acta 2020. [CrossRef]

50. Yamada, T.; Okada, T.; Sakaguchi, K.; Ohfune, Y.; Ueki, H.; Soloshonok, V.A. Efficient Asymmetric Synthesis of Novel 4-Substituted and Configurationally Stable Analogs of Thalidomide. Org. Lett. 2006, 8, 5625-5628. [CrossRef]

51. Soloshonok, V.A.; Cai, C.; Hruby, V.J. Toward Design of a Practical Methodology for Stereocontrolled Synthesis of $x$-Constrained Pyroglutamic Acids and Related Compounds. Virtually Complete Control of Simple Diastereoselectivity in the Michael Addition Reactions of Glycine Ni(II) Complexes with N-(Enoyl)oxazolidinones. Tetrahedron Lett. 2000, 41, 135-139.

52. Yamada, T.; Sakaguchi, K.; Shinada, T.; Ohfune, Y.; Soloshonok, V.A. Efficient asymmetric synthesis of the functionalized pyroglutamate core unit common to oxazolomycin and neooxazolomycin using Michael reaction of nucleophilic glycine Schiff base with $\alpha, \beta$-disubstituted acrylate. Tetrahedron: Asymmetry 2008, 19, 2789-2795. [CrossRef]

53. Sorochinsky, A.E.; Aceña, J.L.; Moriwaki, H.; Sato, T.; Soloshonok, V.A. Asymmetric synthesis of $\alpha$-amino acids via homologation of Ni(II) complexes of glycine Schiff bases; Part 1: Alkyl halide alkylations. Amino Acids 2013, 45, 691-718. [CrossRef] [PubMed]

54. Sorochinsky, A.E.; Aceña, J.L.; Moriwaki, H.; Sato, T.; Soloshonok, V.A. Asymmetric synthesis of $\alpha$-amino acids via homologation of $\mathrm{Ni}(\mathrm{II})$ complexes of glycine Schiff bases. Part 2: Aldol, Mannich addition reactions, deracemization and $(S)$ to $(R)$ interconversion of $\alpha$-amino acids. Amino Acids 2013, 45, 1017-1033. [CrossRef] [PubMed]

55. Aceña, J.L.; Sorochinsky, A.E.; Soloshonok, V.A. Asymmetric synthesis of $\alpha$-amino acids via homologation of $\mathrm{Ni}(\mathrm{II})$ complexes of glycine Schiff bases. Part 3: Michael addition reactions and miscellaneous transformations. Amino Acids 2014, 46, 2047-2073. [CrossRef]

56. Aceña, J.L.; Sorochinsky, A.E.; Moriwaki, H.; Sato, T.; Soloshonok, V.A. Synthesis of fluorine-containing $\alpha$-amino acids in enantiomerically pure form via homologation of $\mathrm{Ni}(\mathrm{II})$ complexes of glycine and alanine Schiff bases. J. Fluorine Chem. 2013, 155, 21-38. [CrossRef]

57. Popkov, A.; De Spiegeleer, B. Chiral nickel (II) complexes in the preparation of ${ }^{11} \mathrm{C}$ - and ${ }^{18} \mathrm{~F}-$ labelled enantiomerically pure $\alpha$-amino acids. Dalton Trans. 2012, 41, 1430-1440. [CrossRef]

58. Wang, Y.; Song, X.; Wang, J.; Moriwaki, H.; Soloshonok, V.A.; Liu, H. Recent approaches for asymmetric synthesis of $\alpha$-amino acids via homologation of $\mathrm{Ni}(\mathrm{II})$ complexes. Amino Acids 2017, 49, 1487-1520. [CrossRef]

59. Romoff, T.T.; Palmer, A.B.; Mansour, N.; Creighton, C.J.; Miwa, T.; Ejima, Y.; Moriwaki, H.; Soloshonok, V.A. Scale-up Synthesis of $(R)$ - and (S)-N-(2-Benzoyl-4-chlorophenyl)-1-(3,4dichlorobenzyl)pyrrolidine-2-carboxamide Hydrochloride, A Versatile Reagent for the Preparation of Tailor-Made $\alpha$ - and $\beta$-Amino Acids in an Enantiomerically Pure Form. Org. Process. Res. Dev. 2017, 21, 732-739. [CrossRef]

60. Moriwaki, H.; Kawashima, A.; Takeda, R.; Kawamura, A.; Soloshonok, V.A. Method for Synthesizing Optically Active $\alpha$-AminoAcid Using Chiral Metal Complex Comprising Axially Chiral N-(2-Acylaryl)-2-[5,7-Dihydro-6H-Dibenzo[c,e]Azepin-6-yl]AcetamideCompound and Amino Acid. U.S. Patent 9,695,112, 4 July 2017.

61. Takahashi, M.; Moriwaki, H.; Miwa, T.; Hoang, B.; Wang, P.; Soloshonok, V.A. Large Scale Synthesis of Chiral (3Z,5Z)-2,7-Dihydro-1H-azepine-Derived Hamari Ligand for General Asymmetric Synthesis of Tailor-Made Amino Acids. Org. Process. Res. Dev. 2019, 23, 619-628. [CrossRef]

62. Takeda, R.; Abe, H.; Shibata, N.; Moriwaki, H.; Izawa, K.; Soloshonok, V.A. Asymmetric synthesis of $\alpha$-deuterated $\alpha$-amino acids. Org. Biomol. Chem. 2017, 15, 6978-6983. [CrossRef]

63. Mei, H.; Hiramatsu, T.; Takeda, R.; Moriwaki, H.; Abe, H.; Han, J.; Soloshonok, V.A. Expedient asymmetric synthesis of (S)-2-amino-4,4,4-trifluorobutanoic acid via alkylation of chiral nucleophilic glycine equivalent. Org. Process. Res. Dev. 2019, 23, 629-634. [CrossRef] 
64. Han, J.; Takeda, R.; Liu, X.; Konno, H.; Abe, H.; Hiramatsu, T.; Moriwaki, H.; Soloshonok, V.A. Preparative Method for Asymmetric Synthesis of (S)-2-Amino-4, 4, 4-trifluorobutanoic Acid. Molecules 2019, $24,4521$. [CrossRef] [PubMed]

65. Mei, H.; Yin, Z.; Miwa, T.; Moriwaki, H.; Abe, H.; Han, J.; Soloshonok, V.A. Convenient Asymmetric Synthesis of Fmoc-(S)-6,6,6-Trifluoro-Norleucine. Symmetry 2019, 11, 578. [CrossRef]

66. Yin, Z.; Moriwaki, H.; Abe, H.; Miwa, T.; Han, J.; Soloshonok, V.A. Large-Scale Asymmetric Synthesis of Fmoc-(S)-2-Amino-6,6,6-Trifluorohexanoic Acid. ChemistryOpen 2019, 8, 701-704. [CrossRef] [PubMed]

67. Yamamoto, J.; Kawashima, A.; Kawamura, A.; Abe, H.; Moriwaki, H.; Shibata, N.; Soloshonok, V.A. Operationally Convenient and Scalable Asymmetric Synthesis of (2S)- and (2R)- $\alpha$-(Methyl)cysteine Derivatives through Alkylation of Chiral Alanine Schiff Base NiII Complexes. Eur. J. Org. Chem. 2017, 2017, 1931-1939. [CrossRef]

68. Li, B.; Zhang, J.; Xu, Y.; Yang, X.; Li, L. Improved synthesis of unnatural amino acids for peptide stapling. Tetrahedron Lett. 2017, 58, 2374-2377. [CrossRef]

69. Takeda, R.; Kawashima, A.; Yamamoto, J.; Sato, T.; Moriwaki, H.; Izawa, K.; Abe, H.; Soloshonok, V.A. Tandem Alkylation-Second-Order Asymmetric Transformation Protocol for the Preparation of Phenylalanine-Type Tailor-Made $\alpha$-Amino Acids. ACS Omega 2018, 3, 9729-9737. [CrossRef]

70. Watson, M.E.; Jamieson, C.; Kennedy, A.R.; Mason, A.M. A reappraisal of the $\mathrm{Ni}$-[(Benzylprolyl)amino]benzophenone complex in the synthesis of $\alpha, \alpha$-disubstituted amino acid derivatives. Tetrahedron 2019, 75, 130485. [CrossRef]

71. Mahindra, A.; Millard, C.J.; Black, I.; Archibald, L.J.; Schwabe, J.W.R.; Jamieson, A.G. Synthesis of HDAC Substrate Peptidomimetic Inhibitors Using Fmoc Amino Acids Incorporating Zinc-Binding Groups. Org. Lett. 2019, 21, 3178-3182. [CrossRef]

72. Vuong, W.; Mosquera-Guagua, F.; Sanichar, R.; McDonald, T.R.; Ernst, O.P.; Wang, L.; Vederas, J.C. Synthesis of Chiral Spin-Labeled Amino Acids. Org. Lett. 2019, 21, 10149-10153. [CrossRef]

73. Tong, J.; Zhao, L.; Li, H.; Wu, C.; Han, X.; Wang, J.; Liu, H. Construction of highly enantiopure $\beta, \beta$-diaryl substituted glycine containing two contiguous stereocenters via asymmetric 1,6 -conjugate addition. Tetrahedron 2018, 74, 3755-3760. [CrossRef]

74. Zhao, L.; Zhou, S.; Tong, J.; Wang, J.; Liu, H. Asymmetric Synthesis of Chiral Trifluoromethyl Containing Heterocyclic Amino Acids. Chin. J. Chem. 2017, 35, 1540-1548. [CrossRef]

75. Levitskiy, O.A.; Grishin, Y.K.; Semivrazhskaya, O.O.; Ambartsumyan, A.A.; Kochetkov, K.A.; Magdesieva, T.V. Individual $\left({ }^{\mathrm{f}, \mathrm{t}} \mathrm{A}\right)$ - and $\left({ }^{\mathrm{f}, \mathrm{t}} \mathrm{C}\right)$-Fullerene-Based Nickel(II) Glycinates: Protected Chiral Amino Acids Directly Linked to a Chiral $\pi$-Electron System. Angew. Chem. Int. Ed. 2017, 56, 2704-2708. [CrossRef] [PubMed]

76. Larionov, V.A.; Savel'yeva, T.F.; Medvedev, M.G.; Stoletova, N.V.; Smol'yakov, A.F.; Gugkaeva, Z.T.; Cruchter, T.; Maleev, V.I. The Selective N-Functionalization of Indoles via aza-Michael Addition in the Ligand Sphere of a Chiral Nickel(II) Complex: Asymmetric Synthesis of (S)-1H-Indole-Alanine Derivatives. Eur. J. Org. Chem. 2019, 3699-3703. [CrossRef]

77. Kukhar, V.P.; Sorochinsky, A.E.; Soloshonok, V.A. Practical synthesis of fluorine-containing $\alpha$-and $\beta$-amino acids: Recipes from Kiev, Ukraine. Future Med. Chem. 2009, 1, 793-819. [CrossRef] [PubMed]

78. Soloshonok, V.A. Highly Diastereoselective Michael Addition Reactions between Nucleophilic Glycine Equivalents and $\beta$-substituted- $\alpha, \beta$-Unsaturated Carboxylic acid Derivatives; a General Approach to the Stereochemically Defined and Sterically $\chi$-Constrained $\alpha$-Amino Acids. Curr. Org. Chem. 2002, 6, 341-364. [CrossRef]

79. Dave, R.; Bader, B.; Meffre, P. G-Fluorinated analogues of glutamic acid and glutamine. Amino Acids 2003, 24, 245-261. [CrossRef]

80. Soloshonok, V.A.; Cai, C.; Hruby, V.J.; Meervelt, L.V.; Mischenko, N. Stereochemically Defined C-Substituted Glutamic Acids and their Derivatives. 1. An Efficient Asymmetric Synthesis of (2S,3S)-3-Methyl- and -3-Trifluoromethylpyroglutamic Acids. Tetrahedron 1999, 55, 12031-12044. [CrossRef]

81. Sorochinsky, A.; Voloshin, N.; Markovsky, A.; Belik, M.; Yasuda, N.; Uekusa, H.; Ono, T.; Berbasov, D.O.; Soloshonok, V.A. Convenient Asymmetric Synthesis of $\beta$-Substituted $\alpha, \alpha$-Difluoro- $\beta$-Amino Acids via Reformatsky Reaction between Davis' N-Sulfinylimines and Ethyl Bromodifluoroacetate. J. Org. Chem. 2003, 68, 7448-7454. [CrossRef]

82. Ueki, H.; Ellis, T.K.; Martin, H.C.; Soloshonok, V.A. Efficient Large-Scale Synthesis of Picolinic Acid Derived Ni(II)-Complexes of Glycine. Eur. J. Org. Chem. 2003, 1954-1957. [CrossRef] 
83. Tokairin, Y.; Soloshonok, V.A.; Konno, H.; Moriwaki, H.; Röschenthaler, G.-V. Convenient synthesis of racemic 4,4-difluoro glutamic acid derivatives via Michael-type additions of Ni(II)-complex of dehydroalanine Schiff bases. J. Fluorine Chem. 2019, 227, 109376. [CrossRef]

84. Tokairin, Y.; Shigeno, Y.; Han, J.; Röschenthaler, G.-V.; Konno, H.; Moriwaki, H.; Soloshonok, V.A. Asymmetric Synthesis of 4,4-(Difluoro)glutamic Acid via Chiral Ni(II)-Complexes of Dehydroalanine Schiff Bases. Effect of the Chiral Ligands Structure on the Stereochemical Outcome. ChemistryOpen 2020, 9, 93-96. [CrossRef] [PubMed]

85. Inoue, M.; Shinohara, N.; Tanabe, S.; Takahashi, T.; Okura, K.; Itoh, H.; Mizoguchi, Y.; Iida, M.; Lee, N.; Matsuoka, M. Total synthesis of the large non-ribosomal peptide polytheonamide B. Nature Chem. 2010, 2, 280-285. [CrossRef]

86. Cai, C.; Soloshonok, V.A.; Hruby, V.J. Michael addition reaction between chiral Ni(II) complex of glycine and 3-(trans-enoyl)ozazolidin-2-ones. A cases of electron donor-acceptor attractive interaction-controlled face diastereoselectivity. J. Org. Chem. 2001, 66, 1339-1350. [CrossRef]

87. Soloshonok, V.A.; Cai, C.; Hruby, V.J. A unique case of face diastereoselectivity in the Michael addition reactions between $\mathrm{Ni}(\mathrm{II})$-complexes of glycine and chiral 3-(E-enoyl)-1,3-oxazolidin-2-one. Tetrahedron Lett. 2001, 41, 9645-9649. [CrossRef]

88. Stierhof, M.; Hansen, K.Ø.; Sharma, M.; Feusssner, K.; Subko, K.; Díaz-Rullo, F.F.; Isaksson, J.; Perez-Victoria, I.; Clarkeg, D.; Hansen, E.; et al. New cytotoxic callipeltins from the Solomon Island marine sponge Asteropus sp. Tetrahedron 2016, 72, 6929-6934. [CrossRef]

89. Tokairin, Y.; Soloshonok, V.A.; Moriwaki, H.; Konno, H. Asymmetric synthesis of (2S,3S)-3-Me-glutamine and $(R)$-allo-threonine derivatives proper for solid-phase peptide coupling. Amino Acids 2019, 51, 419-432. [CrossRef] [PubMed]

90. Saghyan, A.S.; Mkrtchyan, A.F.; Mardiyan, Z.Z.; Hayriyan, L.A.; Belokon, Y.N.; Langer, P. Synthesis of Enantiomerically Enriched Non-Proteinogenic $\alpha$-Amino Acids Using the Suzuki Reaction. ChemistrySelect 2019, 4, 4686-4688. [CrossRef]

91. Rahman, Y.A.; Podolin, P.L.; Carpenter, D.C.; Jin, Q.; Riflade, B.; Dong, X.; Nevins, N.; Keller, P.M.; Mitchell, L.; Tomaszek, T. Azepanone-based inhibitors of human cathepsin S: Optimization of selectivity via the P2 substituent. Bioorg. Med. Chem. Lett. 2011, 21, 4409.

92. Risgaard, R.; Nielsen, S.D.; Hansen, K.B.; Jensen, C.M.; Nielsen, B.; Traynelis, S.F.; Clausen, R.P.J. Development of 2'-Substituted (2S,1'R,2'S)-2-(Carboxycyclopropyl)glycine Analogues as Potent N-Methyl-d-aspartic Acid Receptor Agonists. Med. Chem. 2013, 56, 4071. [CrossRef]

93. Larionov, V.A.; Stoletova, N.V.; Kovalev, V.I.; Smol'yakov, A.F.; Savel'yeva, T.F.; Maleev, V.I. A general synthesis of unnatural $\alpha$-amino acids by iron-catalysed olefin-olefin coupling via generated radicals. Org. Chem. Front. 2019, 6, 1094. [CrossRef]

94. Levitskiy, O.A.; Grishin, Y.K.; Magdesieva, T.V. Stereoselective Electrosynthesis of beta-Hydroxy- $\alpha$-Amino Acids in the Form of NiII-Schiff-Base Complexes. Eur. J. Org. Chem. 2019, 3174-3182. [CrossRef]

95. Jäckel, C.; Seufert, W.; Thust, S.; Koksch, B. Evaluation of the molecular interactions of fluorinated amino acids with native polypeptides. ChemBioChem 2004, 5, 717-720.

96. Jaäckel, C.; Salwiczek, M.; Koksch, B. Fluorine in a native protein environment how the spatial demand and polarity of fluoroalkyl groups affect protein folding. Angew. Chem. Int. Ed. 2006, 45, 4198-4203. [CrossRef]

97. Chiu, H.P.; Suzuki, Y.; Gullickson, D.; Ahmad, R.; Kokona, B.; Fairman, R.; Cheng, R.P. Helix propensity of highly fluorinated amino acids. J. Am. Chem. Soc. 2006, 128, 15556-15557. [CrossRef]

98. Chiu, H.P.; Kokona, B.; Fairman, R.; Cheng, R.P. Effect of highly fluorinated amino acids on protein stability at a solvent-exposed position on an internal strand of protein G B1 domain. J. Am. Chem. Soc. 2009, 131, 13192-13193. [CrossRef]

99. Salwiczek, M.; Koksch, B. Effects of fluorination on the folding kinetics of a heterodimeric coiled coil. ChemBioChem 2009, 10, 2867-2870. [CrossRef]

100. Vagt, T.; Nyakatura, E.; Salwiczek, M.; Jaeckel, C.; Koksch, B. Toward identifying preferred interaction partners of fluorinated amino acids within the hydrophobic environment of a dimeric coiled coil peptide. Org. Biomol. Chem. 2010, 8, 1382-1386. [CrossRef]

101. Nyakatura, E.K.; Reimann, O.; Vagt, T.; Salwiczek, M.; Koksch, B. Accommodating fluorinated amino acids in a helical peptide environment. RSC Adv. 2013, 3, 6319-6322. [CrossRef] 
102. Völler, J.S.; Dulic, M.; Gerling-Driessen, U.I.M.; Biava, H.; Baumann, T.; Budisa, N.; Gruic-Sovulj, I.; Koksch, B. Discovery and investigation of natural editing function against artificial amino acids in protein translation. ACS Cent. Sci. 2017, 3, 73-80. [CrossRef]

103. Buer, B.C.; Chugh, J.; Al-Hashimi, H.M.; Marsh, E.N.G. Using fluorine nuclear magnetic resonance to probe the interaction of membrane-active peptides with the lipid bilayer. Biochemistry 2010, 49, 5760-5765. [CrossRef] [PubMed]

104. De Kort, D.W.; Rombouts, W.H.; Hoeben, F.J.M.; Janssen, H.M.; Van As, H.; van Duynhoven, J.P.M. Scaling Behavior of Dendritic Nanoparticle Mobility in Semidilute Polymer Solutions. Macromolecules 2015, 48, 7585-7591. [CrossRef]

105. Soini, J.; Falschlehner, C.; Liedert, C.; Bernhardt, J.; Vuoristo, J.; Neubauer, P. Norvaline is accumulated after a down-shift of oxygen in Escherichia coli W3110. Microb. Cell Fact. 2008, 7, 30. [CrossRef]

106. Graham, D.W.; Ashton, W.T.; Barash, L.; Brown, J.E.; Brown, R.D.; Canning, L.F.; Chen, A.; Springer, J.P.; Rogers, E.F. Inhibition of the mammalian $\beta$-lactamase renal dipeptidase (dehydropeptidase- I) by Z-2-(acylamino)-3-substituted-propenoic acids. J. Med. Chem. 1987, 30, 1074-1090. [CrossRef] [PubMed]

107. Tsushima, T.; Kawada, K.; Ishihara, S.; Uchida, N.; Shiratori, O.; Higaki, J.; Hirata, M. Fluorinecontaining amino acids and their derivatives. 7. Synthesis and antitumor activity of $\alpha$ - and $\gamma$-substituted methotrexate analogs. Tetrahedron 1988, 44, 5375-5387. [CrossRef]

108. Ojima, I.; Jameison, F.A.; Pete, B.; Radunz, H.; Schittenhelm, C.; Lindner, H.J.; Emith, A.E. Design, synthesis and enzyme inhibitory activities of new trifluoromethyl-containing inhibitors for angiotensin converting enzyme. Drug Des. Discov. 1994, 11, 91-113.

109. Hartman, M.C.T.; Josephson, K.; Szostak, J.W. Enzymatic aminoacylation of tRNA with unnatural amino acids. Proc. Natl. Acad. Sci. USA 2006, 103, 4356-4361. [CrossRef]

110. Shan, W.; Balog, A.; Quesnelle, C.; Gill, P.; Han, W.C.; Norris, D.; Mandal, S.; Thiruvenkadam, R.; Gona, K.B.; Thiyagarajan, K.; et al. BMS-871: A novel orally active pan-Notch inhibitor as an anticancer agent. Bioorg. Med. Chem. Lett. 2015, 25, 1905-1909. [CrossRef]

111. Zhang, Y.K.; Plattner, J.J.; Easom, E.E.; Jacobs, R.T.; Guo, D.; Freund, Y.R.; Berry, P.; Ciaravino, V.; Erve, J.C.L.; Rosenthal, P.J.; et al. Benzoxaborole Antimalarial Agents. Part 5. Lead Optimization of Novel Amide Pyrazinyloxy Benzoxaboroles and Identification of a Preclinical Candidate. J. Med. Chem. 2017, 60, 5889-5908. [CrossRef]

112. Oba, T.; Yamamoto, Y.; Nomiyama, S.; Suenaga, H.; Muta, S.; Tashiro, K.; Kuhara, S. Properties of a trifluoroleucine-resistant mutant of Saccharomyces cerevisiae. Biosci. Biotechnol. Biochem. 2006, 70, 1776-1779. [CrossRef]

113. Mei, H.; Han, J.L.; Takeda, R.; Sakamoto, T.; Miwa, T.; Minamitsuji, Y.; Moriwaki, H.; Abe, H.; Soloshonok, V.A. Practical Method for Preparation of (S)-2-Amino-5,5,5-trifluoropentanoic Acid via Dynamic Kinetic Resolution. ACS Omega 2019, 4, 11844-11851. [CrossRef] [PubMed]

114. Maximilian Bremerich, Carsten Bolm, Gerhard Raabe, and Vadim, A. Soloshonok Design, Synthesis, and Evaluation of $N$-(tert-Butyl)-Alanine-Derived Chiral Ligands-Aspects of Reactivity and Diastereoselectivity in the Reactions with $\alpha$-Amino Acids. Eur. J. Org. Chem. 2017, 3211-3221.

115. Samant, M.P.; White, R.; Hong, D.J.; Croston, G.; Conn, P.M.; Janovick, J.A.; Rivier, J. Structure-Activity Relationship Studies of Gonadotropin-Releasing Hormone Antagonists Containing S-Aryl/Alkyl Norcysteines and Their Oxidized Derivatives. J. Med. Chem. 2007, 50, 2067-2077. [CrossRef]

116. Repine, J.T.; Kaltenbronn, J.S.; Doherty, A.M.; Hamby, J.M.; Himmelsbach, R.J.; Kornberg, B.E.; Taylor, M.D.; Lunney, E.A.; Humblet, C.; Rapundalo, S.T.; et al. Renin inhibitors containing.alpha-heteroatom amino acids as $\mathrm{P} 2$ residues. J. Med. Chem. 1992, 35, 1032-1042. [CrossRef]

117. Li, J.; Song, X.; Zhou, S.; Wang, J.; Liu, H. Asymmetric Synthesis of Chiral $\alpha$-Substituted Mercaptoglycine Derivatives via $\alpha$-Sulfenylation of Ni(II) Complex of Glycine and S-Substituted 4-Methylbenzenesulfonothioate. Chin. J. Chem. 2017, 35, 1383-1390. [CrossRef]

118. Levitskiy, O.A.; Grishin, Y.K.; Paseshnichenko, K.A.; Kochetkov, K.A.; Magdesieva, T.V. Stereoselective electrochemical thioalkylation of glycine in $\mathrm{Ni}(\mathrm{II})$ coordination environment. Tetrahedron Lett. 2018, 59, 2831-2834. [CrossRef] 
119. Larionov, V.A.; Adonts, H.V.; Gugkaeva, Z.T.; Smol'yakov, A.F.; Saghyan, A.S.; Miftakhov, M.S.; Kuznetsova, S.A.; Maleev, V.I.; Belokon, Y.N. The Elaboration of a General Approach to the Asymmetric Synthesis of 1,4-Substituted 1,2,3-Triazole Containing Amino Acids via Ni(II) Complexes. ChemistrySelect 2018, 3, 3107-3110. [CrossRef]

120. Collet, S.; Bauchat, P.; Danion-Bougot, R.; Danion, D. Stereoselective, nonracemic synthesis of $\omega$-borono- $\alpha$-amino acids. Tetrahedron Asymmetry 1998, 9, 2121-2131. [CrossRef]

121. Nian, Y.; Wang, J.; Moriwaki, H.; Soloshonok, V.A.; Liu, H. Analysis of crystallographic structures of Ni(II) complexes of $\alpha$-amino acid Schiff bases: Elucidation of the substituent effect on stereochemical preferences. Dalton Trans. 2017, 46, 4191-4198. [CrossRef]

122. Han, J.L.; Jean, M.; Roussel, C.; Moriwaki, H.; Soloshonok, V.A. Chromatographic approach to study the configurational stability of $\mathrm{Ni}(\mathrm{II})$ complexes of amino-acid Schiff bases possessing stereogenic nitrogen. Chirality 2019, 31, 328-335. [CrossRef]

123. Mei, H.; Jean, M.; Albalat, M.; Vanthuyne, N.; Roussel, C.; Moriwaki, H.; Yin, Z.; Han, J.L.; Soloshonok, V.A. Effect of substituents on the configurational stability of the stereogenic nitrogen in metal (II) complexes of $\alpha$-amino acid Schiff bases. Chirality 2019, 31, 401-409. [CrossRef] [PubMed]

124. Nagaoka, K.; Mei, H.; Guo, Y.; Han, J.; Konno, H.; Moriwaki, H.; Soloshonok, V.A. Michael addition reactions of chiral glycine Schiff base Ni (II)-complex with 1-(1-phenylsulfonyl)benzene. Chirality 2020, 32, 855-893. [CrossRef] [PubMed]

125. Zhou, R.; Pan, Z.; Zhang, Y.; Wu, F.; Jiang, Q.; Guo, L. Base-Promoted Synthesis of $\beta$-Substituted-Tryptophans via a Simple and Convenient Three-Component Condensation of Nickel(II) Glycinate. Molecules 2017, 22, 695. [CrossRef]

126. Wang, J.; Ji, X.; Shi, J.; Sun, H.; Jiang, H.; Liu, H. Diastereoselective Michael reaction of chiral nickel(II) glycinate with nitroalkenes for asymmetric synthesis of $\beta$-substituted $\alpha, \gamma$-diaminobutyric acid derivatives in water. Amino Acids 2012, 42, 1685-1694. [CrossRef]

127. Yang, Z.F.; Xu, C.; Zheng, X.; Zhang, X. Nickel-catalyzed carbodifunctionalization of N-vinylamides enables access to $\gamma$-amino acids. Chem. Commun. 2020, 56, 2642-2645. [CrossRef]

128. Gorteau, V.; Bollot, G.; Mareda, J.; Pasini, D.; Tran, D.H.; Lazar, A.N.; Coleman, A.W.; Sakai, N.; Matile, S. Synthetic multifunctional pores that open and close in response to chemical stimulation. Bioorg. Med. Chem. 2005, 13, 5171-5180. [CrossRef] [PubMed]

129. Baudry, Y.; Pasini, D.; Nishihara, M.; Sakai, N.; Matile, S. The depth of molecular recognition: Voltage-sensitive blockage of synthetic multifunctional pores with refined architecture. Chem. Commun. 2005, 4798-4800. [CrossRef] [PubMed]

(C) 2020 by the authors. Licensee MDPI, Basel, Switzerland. This article is an open access article distributed under the terms and conditions of the Creative Commons Attribution (CC BY) license (http://creativecommons.org/licenses/by/4.0/). 